\title{
LATE CRETACEOUS DINOSAUR EGGSHELLS FROM THE TREMP BASIN, SOUTHERN PYRENEES, LLEIDA, SPAIN
}

\author{
MONIQUE VIANEY-LIAUD AND NIEVES LOPEZ-MARTINEZ \\ Institut des Sciences de l'Evolution, Université Monptellier II, Place Eugène Bataillon, \\ 34095-Montpellier cedex 05-France, and \\ Departamento de Paleontología, Facultad de Ciencias Geológicas, Universidad Complutense, 28040 Madrid, Spain
}

\begin{abstract}
Late Cretaceous dinosaur eggshell assemblages from six localities of the Tremp basin (Southern Pyrences, Lleida, Spain) are studied and compared with those of Southern France, to correlate their temporal succession. Fontllonga 6 reveals the most diverse eggshell assemblage known so far, with seven oospecies, among which one new structural type (Pseudogeckoolithus nodosus new genus and species), a new Ratite-type eggshell (Ageroolithus fontllongensis new genus and species) and a new Prismatoolithidae are described: four other taxa are shared with Southern France. The correlation of both Spanish and French eggshell successions allows us to recognize three main periods characterised by different eggshell assemblages: a lower assemblage with Megaloolithus petralta. M. aureliensis. Prismatoolithus tenuis and P. matellensis from the French Lower Rognacian and the Spanish sites Fontllonga 6 and Moro; a middle one with $M$. siruguei from the Middle Rognacian and Biscarri; and a late one from the Late Rognacian with $M$. mammilare (from Abella and Bastus) and $M$. pseudomamillare (from Suterranya). Some contradictions appear when comparing results with paleomagnetism and charophyte correlations but the eggshell correlations are consistent with other stratigraphic studies.
\end{abstract}

\section{INTRODUCTION}

$\mathbf{T}$ HE BIOTIC and paleoenvironmental changes during the Cretaceous-Tertiary (K/T) transition, extensively studied in marine deposits (e.g., Alvarez et al., 1982; Keller and Barrera, 1990), are less well known in continental ones, which yet are essential for the interpretation of global events (Orth et al., 1981; Lerbekmo et al., 1987). Unfortunately, the geological record of the continental K/T transition can be studied only in a limited number of basins around the world; these deposits have frequent discontinuities (Fasset and Rigby, 1987; Fastowsky, 1987) and their fossil content is scarce, lacking suitable biostratigraphic correlations. A widespread fossil group from continental $\mathrm{K} / \mathrm{T}$ sequences would be useful in biostratigraphy.

Dinosaur eggshells are frequently found in Upper Cretaceous continental deposits and they are often the only fossils found in red beds. They are present in a number of different facies, such as alluvial conglomerates (Erben et al., 1979), fluviatile sandstones and siltstones (Durand, 1989), palustrine limestones (Sahni et al., 1994) and coastal sandstones (Sanz et al., 1995). The paleontological value of eggshells has been considerably improved by parataxonomic diagnosis (Zhao, 1975, 1979; Mikhaïlov, 1991; Vianey-Liaud et al., 1994), allowing their identification in a stratigraphic succession.

In this work, we characterize the dinosaur eggshell assemblages of six localities from the Tremp basin (Upper Cretaceous of Southern Pyrenees, Lleida province, Spain), particularly that from the fragment-rich site Fontlonga 6 , and discuss affinities with the Upper Cretaceous dinosaur eggshells from the Provence basin, correlating both stratigraphic successions and their calibrations with the paleomagnetic sequence.

\section{GEOLOGICAL SETTING}

During the Maastrichtian and the Paleocene, the South Pyrenean foreland basin became progressively filled by a thick succession of nearshore and continental deposits. In the south-central Pyrenees, two lithostratigraphic units were defined by Mey et al., (1968) for this period: the Aren Formation (nearshore marine sandstones) and the Tremp Formation (continental red beds, informally known as "Garumnian" (Rossell, 1967; Liebau, 1973; Krauss, 1990). Both formations interfingered and prograded basinwards (westwards) during a general rise of the sea level (Díaz Molina, 1987). The Aren Formation corresponds to barrier islands, strand-plain and estuary deposits, and the
Tremp Formation to lagoonal, marshes and fluvial deposits (Nagtegaal et al., 1983; Díaz Molina, 1987).

Thrust tectonics during the Pyrenean orogeny caused the incorporation of the basin-fill into several tectonic units. In the studied area, the Montsec thrust separated the Tremp and the Ager synclines (Figure 1). This shortening has been estimated as about $15 \mathrm{~km}$ in a mainly north-south direction (Garrido Megías and Ríos Aragiies, 1972; Vergés and Muñoz, 1990).

The main locality studied here (Fontllonga 6 ) is situated in the Ager syncline, the other five egg sites being in the Tremp syncline (Figure 1). The Tremp Formation in Fontllonga reaches about $600 \mathrm{~m}$ in thickness. The lithology consists mainly of reddish claystones, siltstones and sandstones, and minor white limestones. In this area, the Aren Sandstone is not represented, the Tremp Formation lying on marine bioclastic calcarenites containing foraminifera and rudists (Calizas de Les Serres, Souquet, 1967) interbedded with lacustrine limestones (Lopez-Martinez et al., 1996).

The lower part of the Tremp Formation, containing the $\mathrm{K} / \mathrm{T}$ boundary, was described in the Fontllonga section by Galbrun et al. (1993), who divided it into three units: two carbonate units (named units 1 and 3 ) and a clastic unit lying in between (named unit 2). The $\mathrm{K} / \mathrm{T}$ boundary was placed in the section according to paleomagnetic measurements and fossil content (pollen, charophytes; Galbrun et al., 1993; Figure 2). These authors interpreted this section as deposits of fluvial and lacustrine freshwater environments (see also Rossell and Llompart, 1988; Cuevas et al., 1989). Alternately, these deposits were interpreted as peritidal and estuarine in nature, passing to marine westwards. This interpretation was based on the sigmoidal cross-stratification indicating tidal influence, and marine fossil content (foraminifera, Girvanella, rays) recognized from both units 1 and 2, and particularly abundant westwards (Álvarez-Sierra et al., 1994; Soler Gijón and López-Martínez, 1995; Arribas et al., 1996).

Dinosaur eggshells were recovered from the lower part of unit 2 (see Figure 2, Fontllonga 6 marked F6), approximately $25 \mathrm{~m}$ above the base; preliminary studies were made by Moratalla (1993) and Álvarez-Sierra et al. (1994). The fossils come from a grey oncolitic level containing large vertebrate bones (dinosaurs, crocodiles, turtles), fishes (rays, holosteans) ostracods and charophytes, mainly Septorella spp. (Galbrun et al., 1993; Álvarez-Sierra et al., 1994; Soler Gijón and López-Martínez, 1995). The bed is situated in a 10m-thick detritic sequence, 


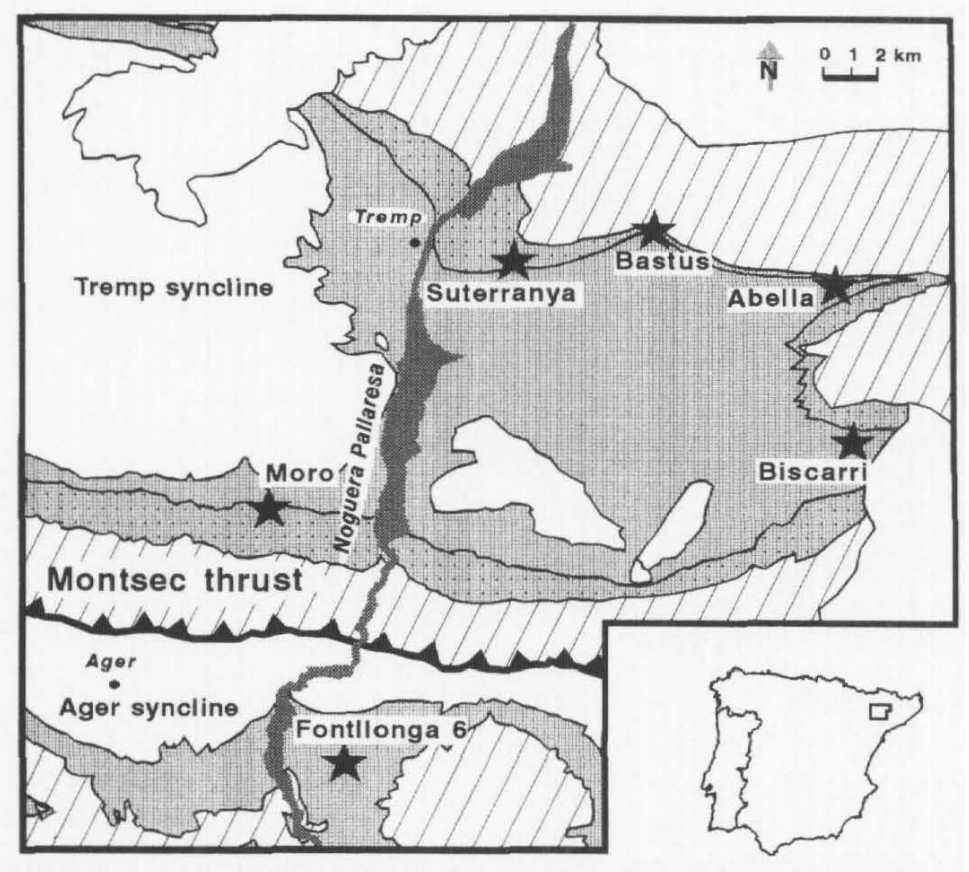

Aren Sandstone (Camp.-Maastrich.)

Tremp Fm. (Maastrich.-Paleocene)

Upper Cretaceous and older

Eocene and younger

FigurE 1 -Geological map of the Tremp and Ager synclines (Tremp basin, Lleida province, Spain), and location of the eggshell localities. Based on Losantos et al. (1989).

made of fine-grained sandstone sheets thickening upwards and separated by siltstones with floated plant debris. The streams producing the deposits probably gathered and transported the egg fragments from various environments.

Galbrun et al., (1993) dated unit 2 from late Maastrichtian to lower Paleocene, using charophytes, pollen and paleomagnetism. The section measured by these authors slightly differs from that of Ardévol (in Álvarez-Sierra et al., 1994), which is used here. The paleomagnetic measurements of the former authors were placed in the new section (Figure 2), and the paleomagnetic succession agrees with the previous interpretation of the chron sequence. According to these data, Fontllonga 6 is situated in the lower part of the chron 31R. The geochronology of the Maastrichtian marine stage, as well as its calibration in the paleomagnetic scale has changed following improvements of the marine biostratigraphy (Gradstein et al., 1995). According to these authors, the Campanian-Maastrichtian boundary is situated at the end of chron $32 \mathrm{~N} 2 \mathrm{n}$ at $71.3 \mathrm{Ma}$. The age of Fontllonga 6 would therefore be early Maastrichtian.

Other dinosaur eggshells localities in the Tremp syncline are shown in Figure 1. They come from a diverse array of facies: grey marine sandstones (Suterranya), red backshore sandstones (Bastús), both in the Aren Formation, and grey lagoonal marls (Biscarri) and conglomerates (Abella), both in the Tremp Formation. The stratigraphic position of Biscarri, Abella, and Suterranya are detailed in Sanz et al. (1995). The Moro eggshells

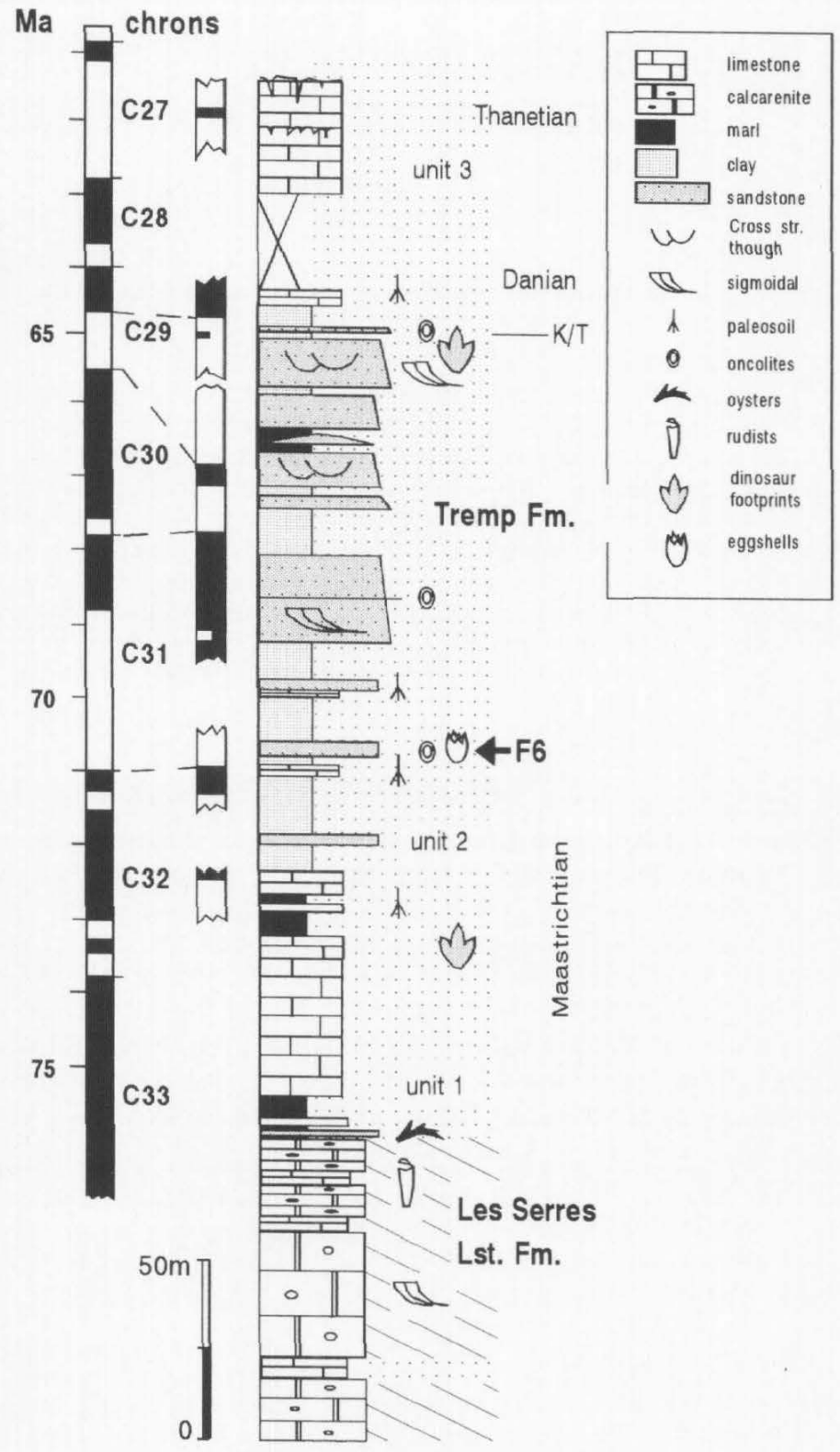

\section{Fontllonga}

FigurE 2-Fontllonga section, and location of the eggshell assemblage (Fontllonga $6=$ F6). Left: magnetostratigraphic results and interpretation according to Galbrun et al. (1993).

are found in the uppermost level of the Aren Formation, below grey marls with rudists of the Tremp Formation (Pons, 1977).

\section{DINOSAUR EGGSHELLS}

The processing of nearly one ton of grey calcareous sands from the fossiliferous locality Fontllonga 6 yielded numerous small eggshell fragments, most with a tubospherulitic tuberculate eggshell type belonging to the dinosauroid oospecies Megaloolithus petralta Vianey-Liaud et al., (1994). Some thinner frag-

Figure 3-Megaloolithus eggshell fragments from Fontllonga 6. SEM photographs. 1-4, (FLL6-50-52, 54), 6, 7, (FLL6-55), outer surfaces of $M$. petralta, different stages of wear (worn to unworn). 5, (FLL6-53), radial broken section, briefly etched with acid, of $M$. aff. aureliensis. 6, (FLL655 ), radial broken section, briefly etched with acid, of $M$. petralta; 7 , same, enlarged, showing growth lines and limits of crystals; 8 , $M$. petralta eggshell fragment from the type locality Roquehautes Grand Creux (Provence, France), RHG-C-10, coll. Université Montpellier II, outer surface. 


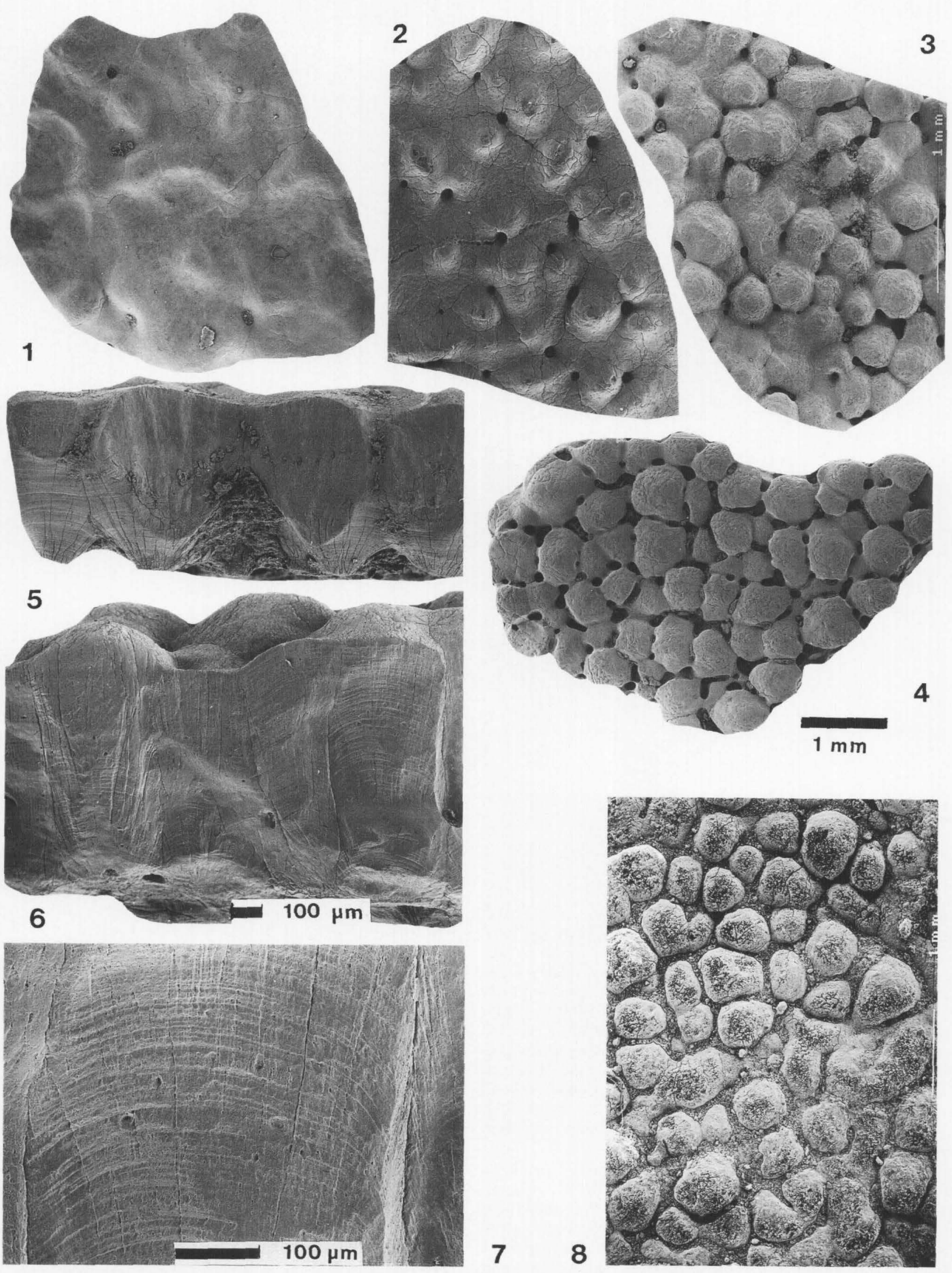



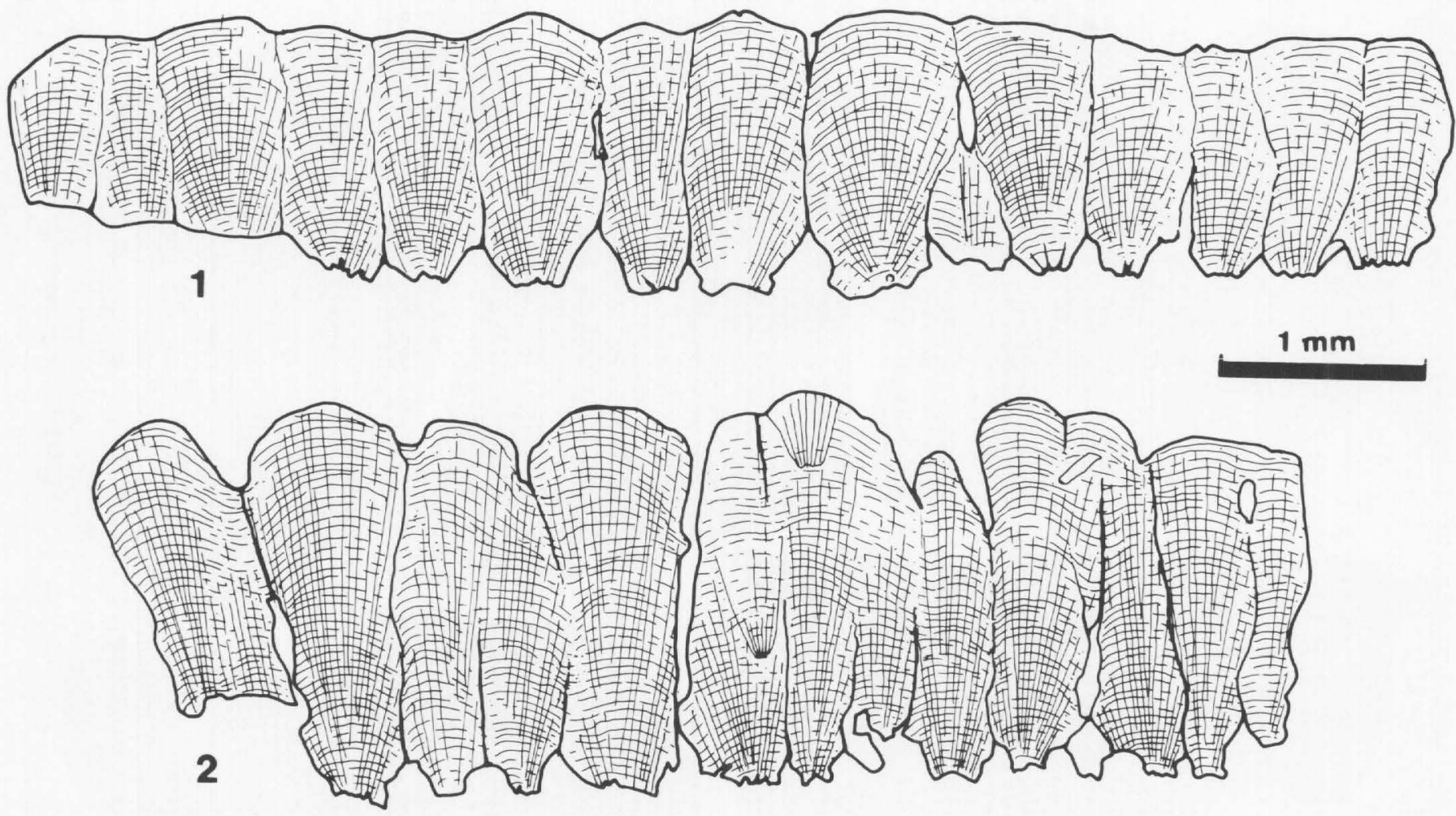

$1 \mathrm{~mm}$

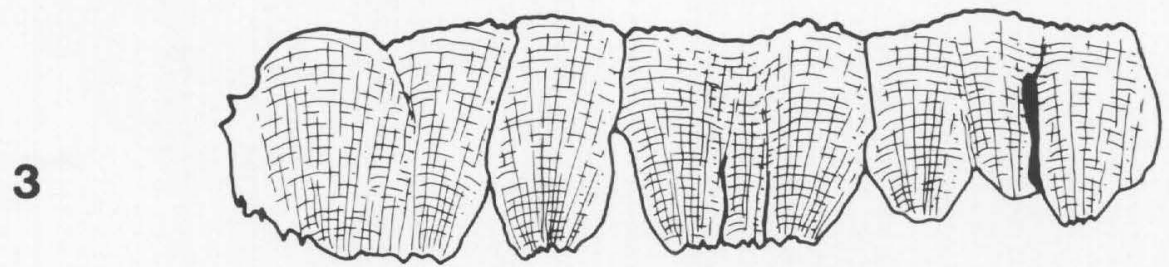

FIGURE 4-Drawings of thin sections of Megaloolithus eggshell fragments from Fontllonga 6. 1, FLL6-30, M. petralta; 2, FLL6-31, M. petralta, thicker specimen. 3, FLL6-32, cf. M. aureliensis.

ments are tentatively referred to Megaloolithus aureliensis. Among the smooth or slightly ornamented eggshells five oospecies were identified, four of them with a dinosauroid prismatic eggshell, including first Prismatoolithus tenuis Vianey-Liaud and Crochet, 1993, and second a new form perhaps close to $P$. matellensis Vianey-Liaud and Crochet, 1993. Third, a new unique type close to the Prismatoolithidae is unnamed here because of limited material. The fourth one is similar to the geckoid type by its pore system but it belongs to the structural prismatic morphotype; accordingly it is named Pseudogeckoolithus nodosus n. gen. n. sp. The fifth oospecies, Ageroolithus fontllongensis $\mathrm{n}$. gen. $\mathrm{n}$. $\mathrm{sp}$. belongs to the ornithoid ratite morphotype.

The material was studied in radial thin sections $(25 \mu \mathrm{m}$ to 30 $\mu \mathrm{m}$ thick) using polarizing light microscopy (PLM) and observed by scanning electron microscopy (SEM). Specimens used for SEM observations were unprocessed or subjected to 10 to 15 seconds of etching in formic or hydrochloric acid. The fossil material is deposited at the Departamento de Paleontologia, Universidad Complutense de Madrid (collection numbers: Fon- tllonga 6, FLL6-1 to 424; Suterranya, SUT-1 to 84; Abella, AB-1 to 10; Bastus, BST 1 to 100 ; Biscarri, BIS-1 to 1000).

\section{SYSTEMATIC PALEONTOLOGY}

Basic organizational group DINOSAUROID Structural morphotype TUBOSPHERULITIC oo-family Megaloolithidae Zhao, 1979

Genus Megaloolithus Vianey-Liaud et al., 1994 MEGaloolithus PETRALTA, Vianey-Liaud et al., 1994 Figures 3, 4

Diagnosis.—see Vianey-Liaud et al., 1994, p. 163-168.

Type locality and age.-Roquehautes Grands Creux, (Aix basin, Provence, France); Lower Rognacian (=? Upper Campanian-Lower Maastrichtian).

Material.-Only small fragments, but well preserved, better than those from the type-locality (FLL6-30 to 34, 50 to 55, 100 to 199,221 to 424 ).

Description.-External surface with nodes 0.27 to $0.97 \mathrm{~mm}$ (average, $0.58 \mathrm{~mm}$ ) in diameter, a little larger than those of the type specimens $(0.37$ to $0.70 \mathrm{~mm}$; average, $0.50 \mathrm{~mm})$ and some 
TABLE 1 -Measurements of the Tubospherulitic eggshell fragments from Fontllonga 6 (Megaloolithus petralta and M. aureliensis).

\begin{tabular}{lccccc}
\hline \hline \multicolumn{1}{c}{ Eggshell thickness } & $\mathrm{n}$ & Min. & Mean & Max. & SD \\
\hline M. petralta + M. aureliensis; unworn & 94 & 1.06 & 1.56 & 1.94 & 0.207 \\
M. petralta + M. aureliensis; worn & 92 & 0.87 & 1.38 & 1.79 & 0.187 \\
Prismatoolithus tenuis & 39 & 0.24 & 0.35 & 0.52 & 0.069 \\
$\begin{array}{l}\text { Nodes diameter } \\
\quad \text { Megaloolithus petralta }\end{array}$ & 237 & 0.27 & 0.58 & 0.97 & 0.148 \\
\hline
\end{tabular}

of them are eroded. The nodes are very irregular, as seen in $M$. petralta from Roquehautes (Provence), mostly isolated, but some are linked in short chains. Pores are irregularly scattered around nodes, sometimes isolated or sometimes grouped. Pore diameters vary from $50 \mu \mathrm{m}$ to $120 \mu \mathrm{m}$, pore canal diameters vary from $40 \mu \mathrm{m}$ to $100 \mu \mathrm{m}$.

In thin sections, as well as in fragments observed by SEM, the growth lines are well preserved, clearly arched, from the base to the top of long fan-shaped units. On the inner surfaces, the main part of the spherulites are worn with spaces between them enlarged. Rare extra-spherulites occur in generally thicker specimens. The shell thickness varies, especially with wear (Table 1 ).

Comparisons and discussion.-These eggshells are thicker than those of Megaloolithus aureliensis, and somewhat thinner than $M$. petralta from the type locality $(1.12 \mathrm{~mm}$ to $2.09 \mathrm{~mm}$; average $1.76 \mathrm{~mm}$ ) or $M$. mamillare ( 1.2 to $2.2 \mathrm{~mm}$, average 1.70 $\mathrm{mm}$ ) from the Aix Basin. The size of nodes and the shape of units are closer to those of $M$. petralta than to those of $M$. mamillare.

The difference between these two oospecies lies in node diameters, unit shapes and egg size and shape. In typical $M$. mamillare, the very irregular nodes reach larger diameters (mainly 0.6 to $1.0 \mathrm{~mm}$ ) than in $M$. petralta (mainly 0.4 to 0.6 $\mathrm{mm}$ ), and the units are wider and less elongated. The eggs of $M$. mamillare are spherical (about $20 \mathrm{~cm}$ in diameter), and those of $M$. petralta are ovoid $(19 \mathrm{~cm} \times 14 \mathrm{~cm})$. Unfortunately the shape and size of the eggs from Fontllonga 6 are not known.

\section{cf. Megaloolithus Aureliensis, Vianey-Liaud et al., 1994 \\ Figures 3.5, 4.3, 5}

Description and discussion.- Some thinner fragments $(0.8 \mathrm{~m}$ to $1.09 \mathrm{~mm}$ ) (FLL6-32, 53, 200 to 220) from Fontllonga 6 are similar to $M$. aureliensis. The histogram of all the tuberculate eggshell thicknesses is asymmetrical towards the thin eggshells (Figure 5) which probably means that both species, $M$. petralta and $M$. aureliensis are mixed. The thin eggshells show the same wear pattern observed on specimens of $M$. aureliensis from Roquehautes (Provence). Wear and dissolution have obliterated some nodes and left others, giving an irregular node pattern. On unworn $M$. aureliensis, nodes are less tightly grouped than in $M$. petralta. This node pattern, with the same degree of wear, looks like that of $M$. pseudomamillare from Les Bréguières (eastern Arc Basin). This oospecies is thicker than M. aureliensis, about the same thickness as $M$. petralta, but the eggs of $M$. pseudomamillare are spherical and larger than those of the two ovoid types.

The systematic attribution of these small isolated fragments is difficult. Because of their thinness and growth lines clearly arched from the base to the top of units, we have put them together with $M$. aureliensis.

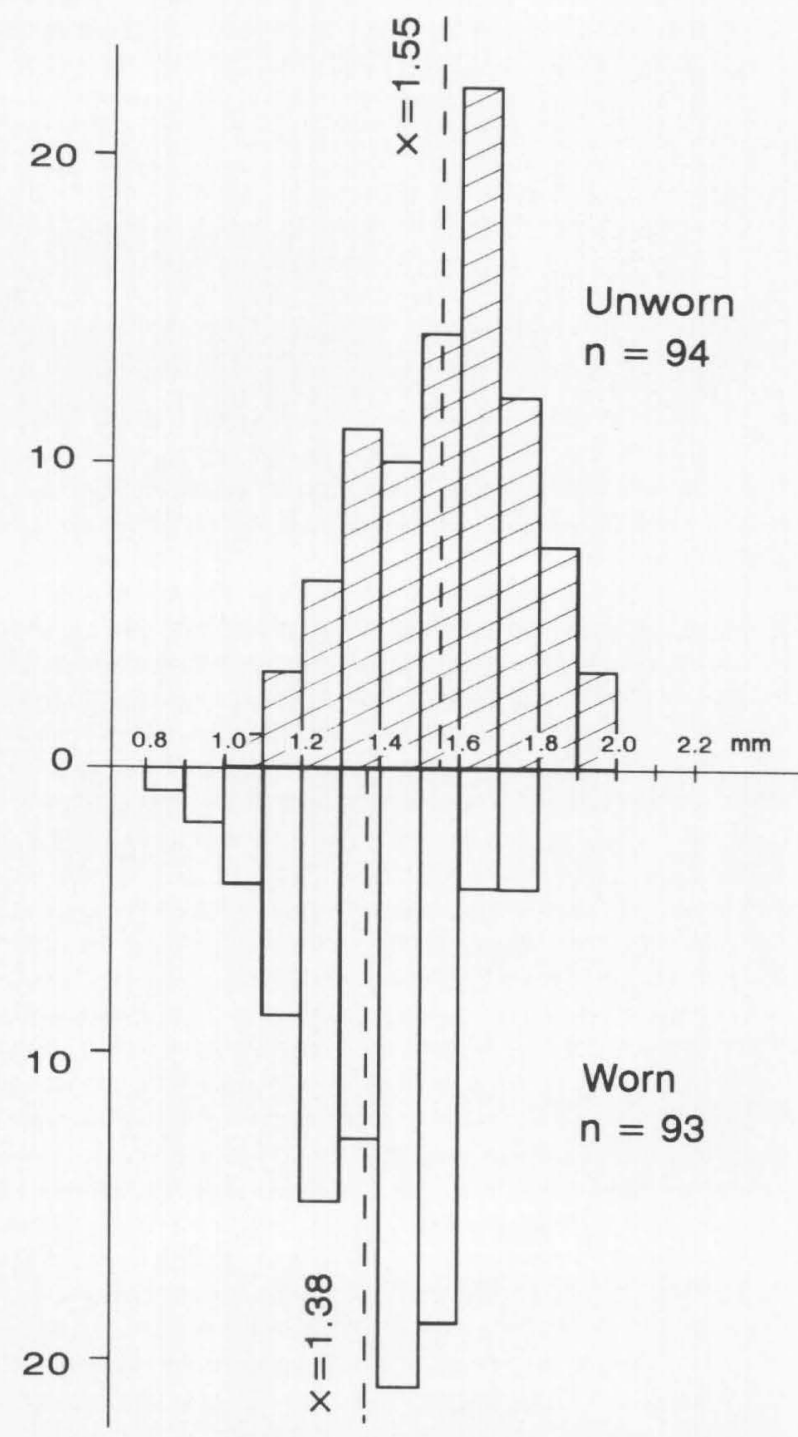

FIGURE 5-Histogram of eggshell fragment thickness of $M$. petralta and M. aff. aureliensis from Fontllonga 6 .

Basic organizational group DINOSAUROID Structural morphotype PRISMATIC oo-family PrismatoOlithidae Hirsch, 1994

Remarks.-Four types of eggshell fragments can be referred to the prismatic structural morphotype. Three of them do not show clear vertical borders between units, and the growth lines have continuous horizontal striations. The extinction pattern is sharp and columnar. These three types differ by their thickness, the width of the spherulites in the mammillary layer, and their ornamentation. Two of them are referred here to the same oogenus.

\section{Prismatoolithus Zhao and $\mathrm{Li}, 1993$}

Remarks.-The same taxon Prismatoolithus was independently created by three authors nearly at the same time: Zhao and Li (1993), Vianey-Liaud and Crochet (1993), and Hirsch (1994). As the paper of Zhao and Li was the first published, in April 1993 (while that of Vianey-Liaud and Crochet appeared in September 1993 and Hirsch's in 1994), they must be considered as the authors of the genus name. 

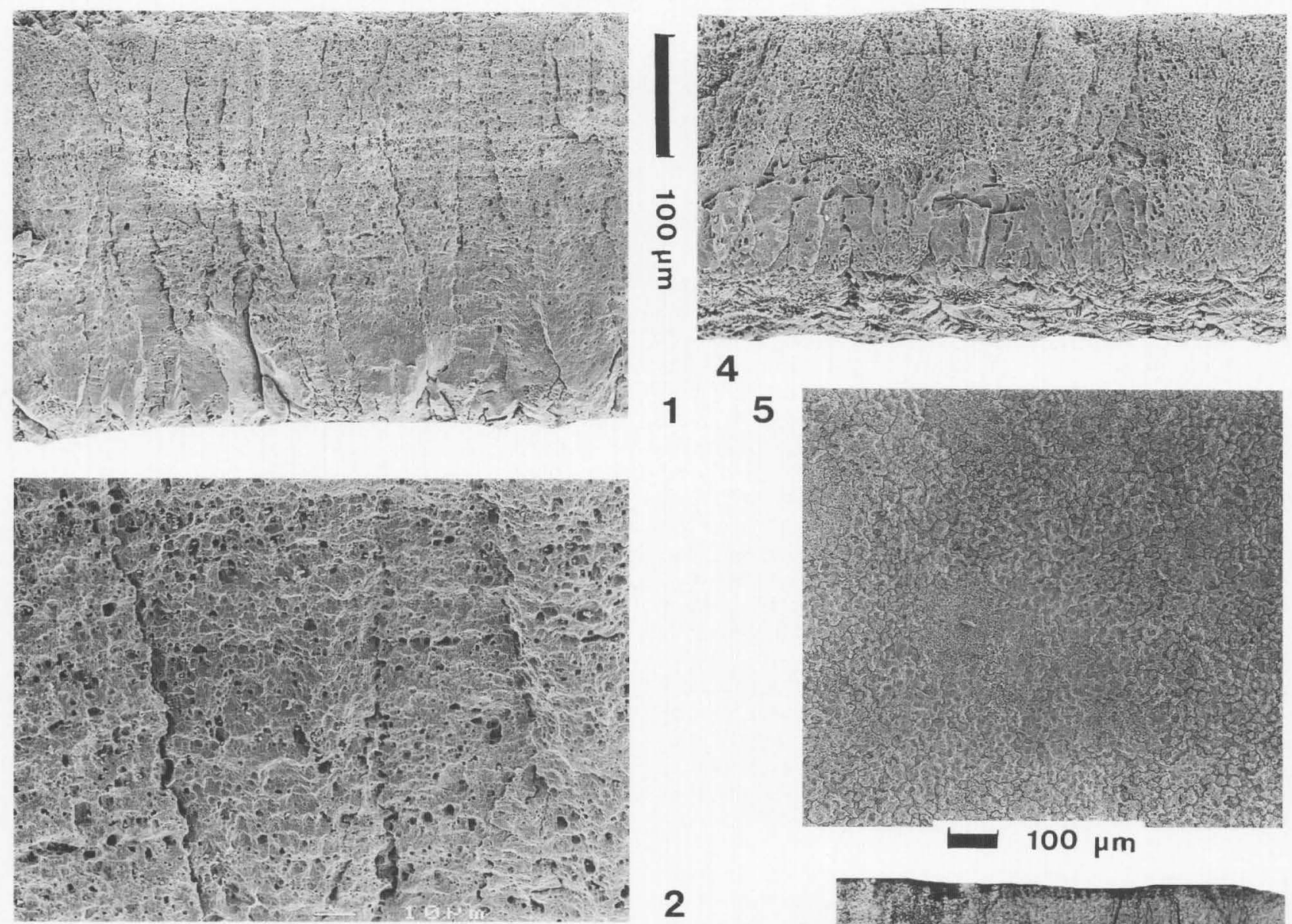

\section{5}

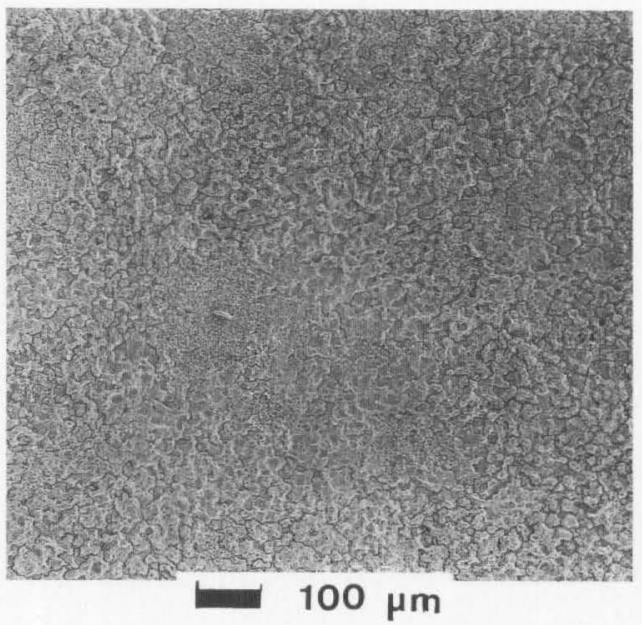

2

3
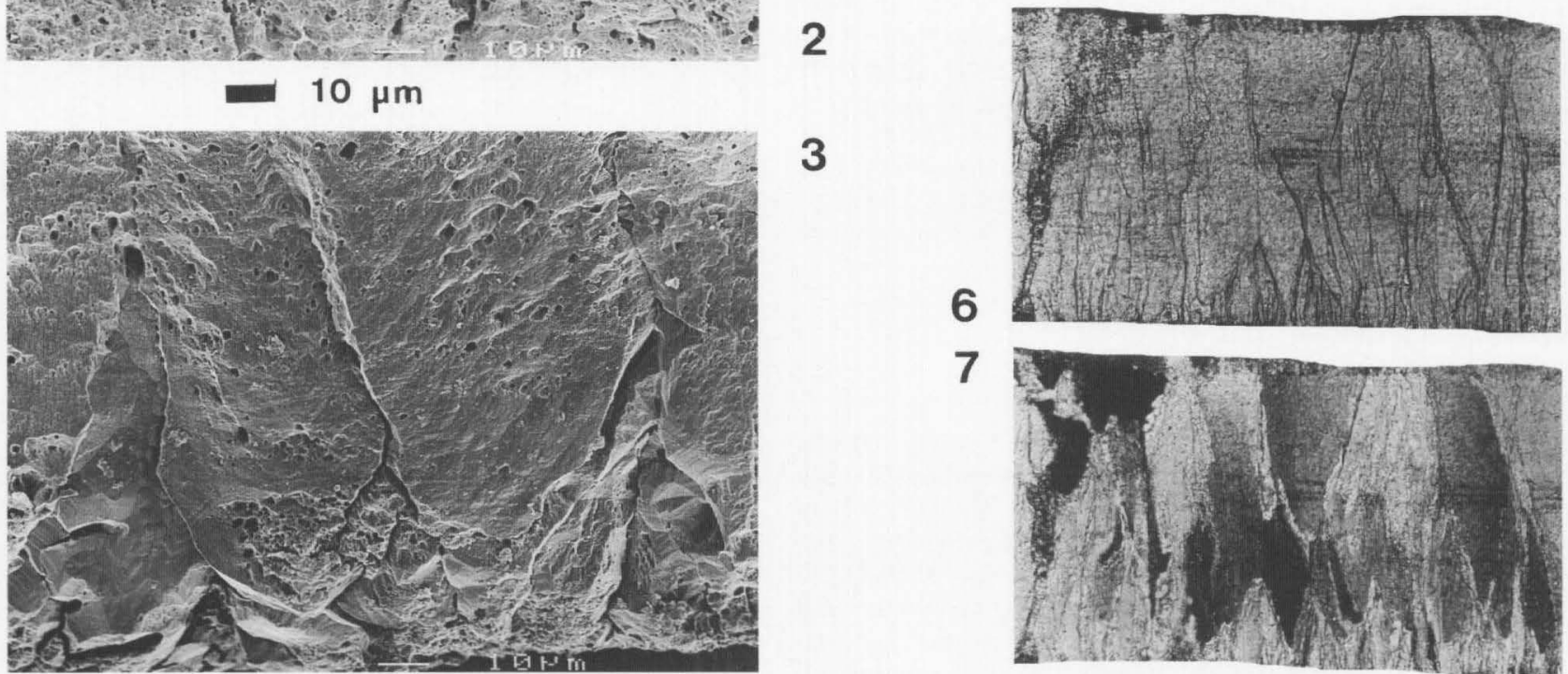

7

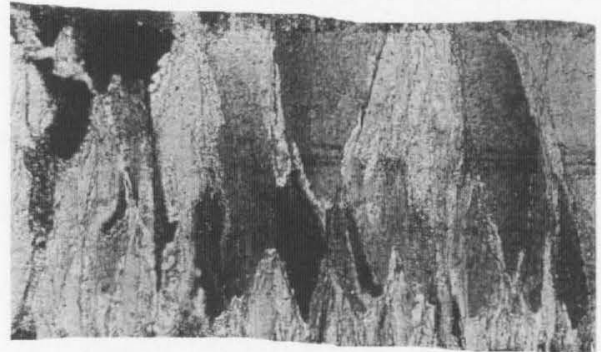

FIGURE 6-Prismatoolithus tenuis eggshell fragments from Fontllonga 6. 1-5, SEM photographs. 1-3, radial section, rapidly etched, FLL6-61; 5, outer surface, FLL6-65; 6-7, thin sections of FLL6-62; 6, not polarized; 7 , polarized.

The morphological and structural characters of the eggshell fragments given by Zhao and $\mathrm{Li}$ are nearly the same as those used by Vianey-Liaud and Crochet to define Prismatoolithus: slender interlocking eggshell units with prisms; thin cone layer; transition between cone layer (wedges) and columnar layer (prisms) gradual; outer surface smooth; oval to circular pore openings; vertical and narrow pore canals. There are slight variations in eggshell thickness, ratio between mammillary layer and prismatic layer, and ornamentation. The two late Cretaceous types studied by these authors have different thicknesses (Prismatoolithus tenuis: $0.3 \mathrm{~mm}-0.6 \mathrm{~mm}$; $P$. gebiensis: $1.06 \mathrm{~mm}-1.22 \mathrm{~mm}$ ). Prismatoolithus tenuis shows some rare, small, irregular flat pits, whereas $P$. gebiensis is smooth. 

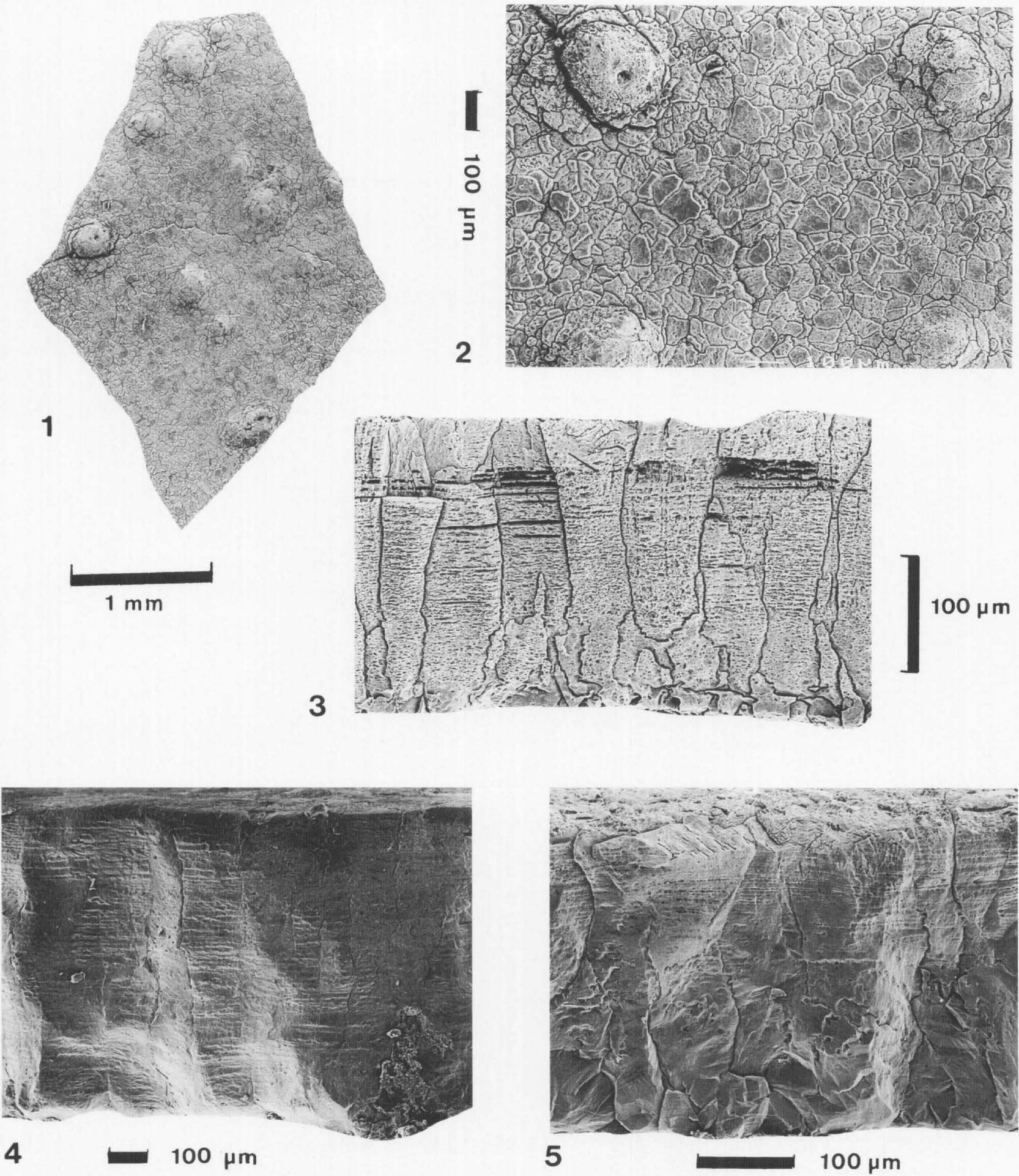

FIGURE 7-Fontllonga 6. 1-3, Pseudogeckoolithus nodosus, FLL6-14, SEM photographs. 1, outer surface; 2, same, showing a pore opening in a node; 3, radial section, briefly etched. 4, Prismatoolothidae nov. gen. cf. Prismatoolithus matellensis, FLL6-11. 5, ? Prismatoolithidae n.g.n.sp., FLL6-15.

The structure of the late Jurassic "Prismatoolithus" coloradorensis Hirsch (1994) is somewhat different. The width of the spherulites is more important than in the late Cretaceous forms, giving wider prisms. The prisms are oblique and the pore canal oblique and wide. Thus, it appears that the oospecies " $P$ ". coloradorensis must be referred to another genus.
Prismatoolithus tenuis

Vianey-Liaud and Crochet, 1993

Figures $6.1,6.3,6.5$

Diagnosis.-See Vianey-Liaud and Crochet, 1993, p. 163.

Type-locality and age.-Pioch-Herbaut (Languedoc, France); ?Lower Rognacian (=?upper Campanian-lower Maastrichtian). 

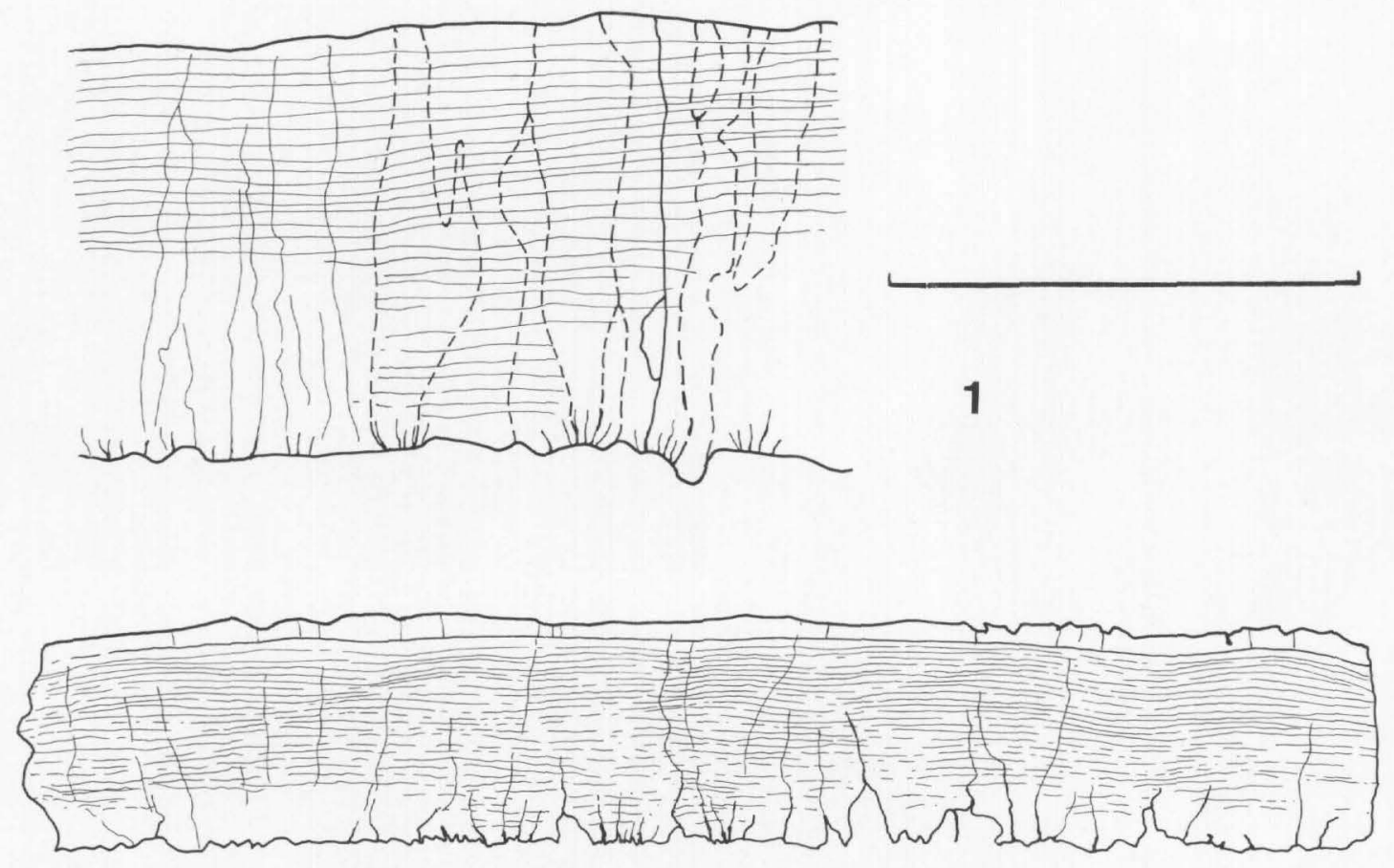

2
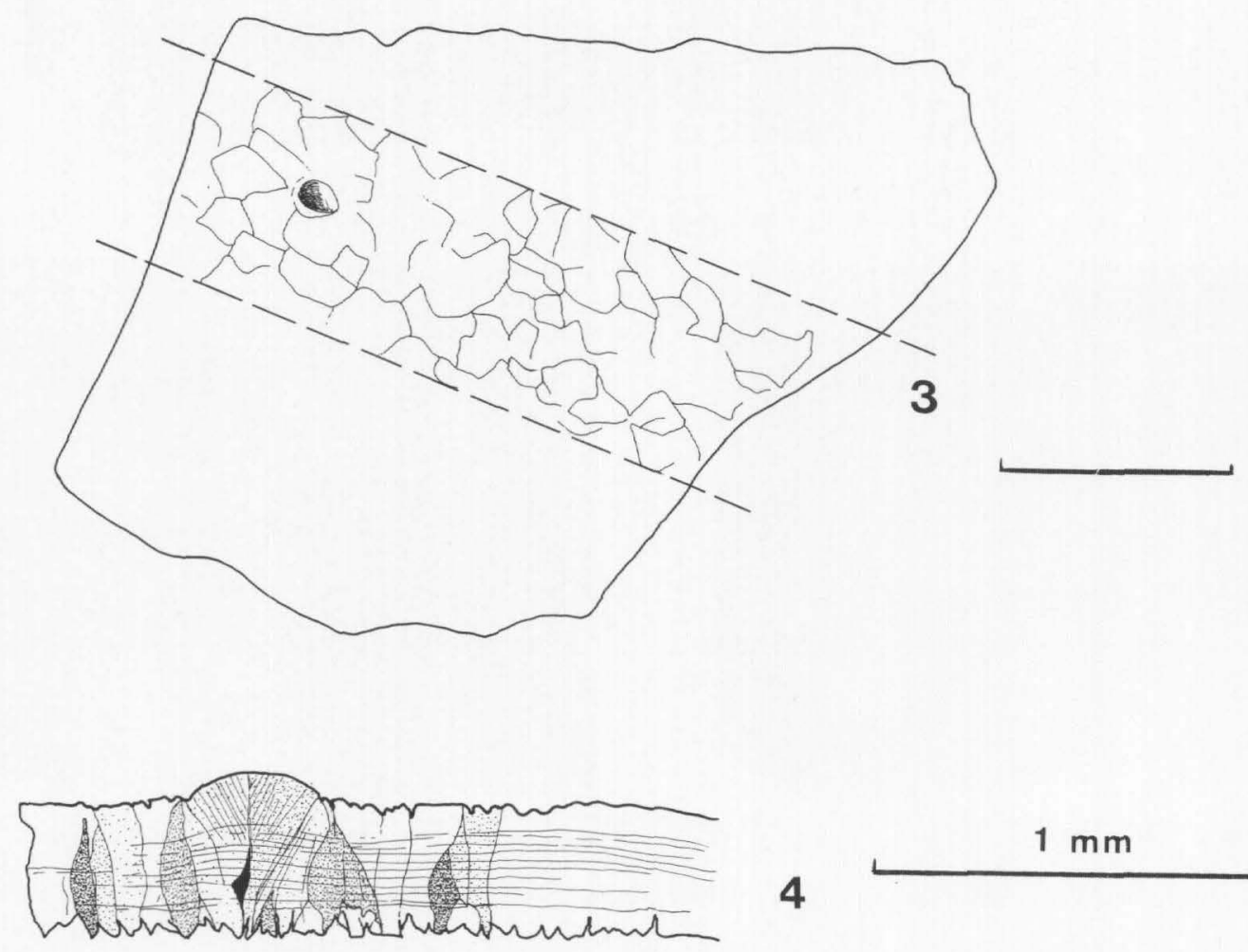

$1 \mathrm{~mm}$

4

FIGURE 8-Fontllonga 6. 1, Prismatoolithidae n. sp. aff. Prismatoolithus matellensis, FLL6-11, radial section, briefly etched. 2, ? Prismatoolithidae nov., FLL6-15, drawing of a radial thin section, showing the thick mammillary layer, the wide prisms and a thin recrystallized outer layer. 3 , ? Prismatoolithidae nov., FLL6-15, outer surface, briefly etched, showing a pore opening and the limits of the prisms. 4, drawing of a thin section of Pseudogeckoolithus nodosus, FLL6-14, in polarized light. 

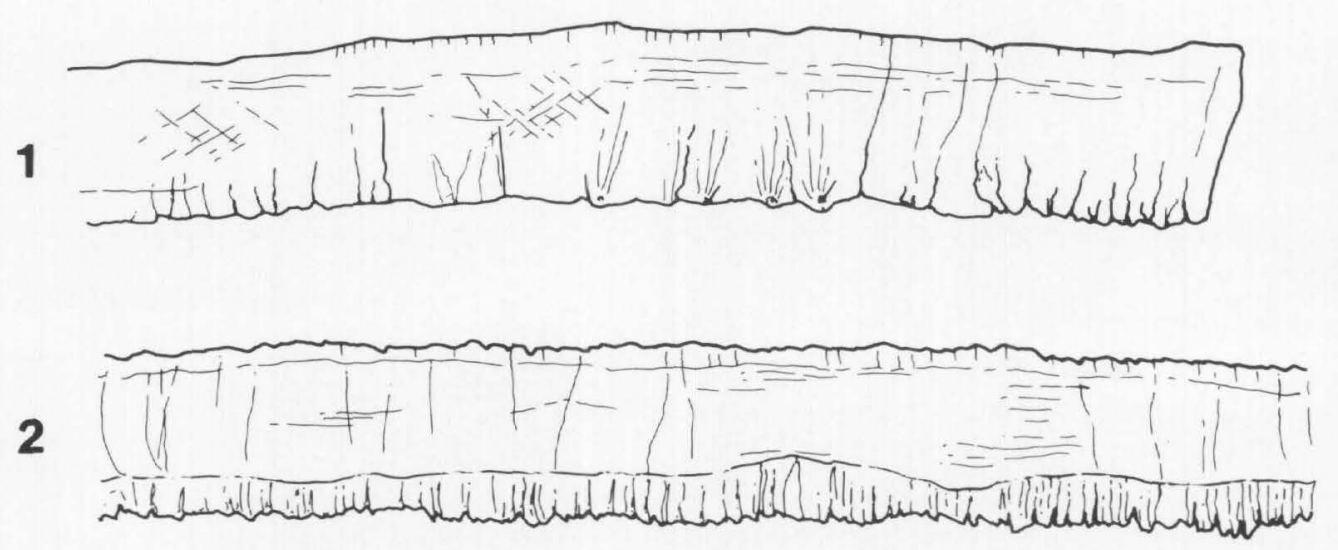

$1 \mathrm{~mm}$

FIGURE 9-Ageroolithus fontllongensis, from Fontllonga 6, drawings of thin sections. 1, FLL6-3, slightly recrystallized; 2, FLL6-13, strongly recrystallized, particularly in the mammillary layer, and in a thin outer layer.

Material.-About forty fragments were collected in Fontllonga 6 (FLL6-16, 18, 19, 60 TO 96).

Description.-Thickness between $0.24 \mathrm{~mm}$ to $0.52 \mathrm{~mm}$ (average, $0.35 \mathrm{~mm}$ ). Outer surface generally smooth. Some rare fragments show the same ornamentation as that of the fragments from Pioch Herbaut, i.e., some rare flat pits, irregularly scattered on the outer surface. Tops of the crystallites sometimes visible. Inner surface weathered, and spherulites quite eroded. The SEM observation shows the gradual transition between wedges and columns. Horizontal striations are more clear in the columns than in the wedges.

Prismatoolithus n. sp., aff. P. matellensis Vianey-Liaud and Crochet, 1993

Figures. 7.4, 8.1

Description and discussion.-Two thicker fragments ( $1 \mathrm{~mm}$ ) from Fontllonga 6 (FLL6-11,12) were compared to the rare fragments of $P$. matellensis from Pioch Herbaut that show the same thickness. They are clearly Prismatoolithus, with cone layer gradually passing to prismatic layer, with vertical irregular prisms and continuous horizontal growth lines. The rare pore canals are straight and relatively wide (about $100 \mu \mathrm{m}$ ), while the unique pore canal measured for the $P$. matellensis type is 50 $\mu \mathrm{m}$ in diameter. Inner and outer surfaces eroded. For this reason, the external surface appears irregular. On one specimen, after etching, the limits of the irregular prisms are visible. On the inner surface, the diameters of worn spherulites appear relatively wide $(0.15 \mathrm{~mm}$ to $0.30 \mathrm{~mm})$; they seem to be smaller in $P$. matellensis $(0.07 \mathrm{~mm}$ to $0.11 \mathrm{~mm})$.

Since we do not know either the variability of the eggshells from Pioch Herbaut or that from Fontllonga 6, the identity of both eggshells cannot be stated with certainty.

oo-family ?Prisma TOOLITHIDAE Hirsch, 1994

? Prismatoolithidae new genus and species

Figures 7.5, 8.2, 8.3

Description and discussion.-A unique specimen from Fontllonga 6 (FLL6-15), as thin as some specimens of $P$. tenuis $(0.50$ $\mathrm{mm}$ ), but showing a different structure. The outer surface is smooth, but not completely even. Etching shows the net made by the sections of the irregular prisms. One oval pore opening $(80 \mu \mathrm{m} \times 160 \mu \mathrm{m})$ is distinct. Inner surface with relatively large spherulites with spaces between them.
In thin sections, mammillary layer thick in comparison to prismatic layer ( $1 / 4$ of the whole thickness). Diameter of the spherulites can reach $0.24 \mathrm{~mm}$, which is wide compared to the Prismatoolithidae from the same locality. Thus, the prisms are relatively wide. Growth striations are not completely horizontal in the prismatic layer, but slightly undulating. A thin outer layer corresponds to a weathered and recrystallized zone.

This specimen is clearly a new form, and must be named when more material is found.

\section{Basic organizational group DINOSAUROID}

Structural morphotype ?PRISMATIC oo-family unnamed

PSEUDOGECKOOLITHUS new genus PSEUDOGECKOOLITHUS NODOSUS new species Figures 7.1-7.3, 8.4

Diagnosis.-Prismatic thin eggshell $(0.30 \mathrm{~mm})$ with short mammillary layer ( $1 / 10$ to $1 / 8$ of the whole thickness); outer surface with rare irregular nodes; pore openings generally on top of the node (shape and size of egg unknown).

Holotype.-FLL6-14, thin section and fragment.

Type locality and age.-Fontllonga 6 (Lleida, Spain); Early Maastrichtian (Chron 31R).

Material.-Six fragments (FLL6-14, 17).

Etymology.-From the false geckoid aspect of the pores, which are placed on nodes as in the gecko eggshell type, but having a prismatic structure different from that of the gecko eggshells.

Description.-Two thin fragments $(0.30 \mathrm{~mm}$, and $0.35 \mathrm{~mm}$ under a node) bear small irregular scattered knobs or nodes on their outer surfaces. The pore canals open in three of these nodes; another pore opening is localized at the base of the node. After a short etching, the outer surface showed a network of irregular prisms. This clear prismatic structure shows a narrow mammillary zone ( $1 / 10$ to $1 / 8$ of the whole thickness). The prisms are clearly visible under PLM. Horizontal growth lines appear in the median part of the thin sections, underlined by mineralizations. Crystallites diverge in node, and growth-lines undulate.

Discussion.-Pseudogeckoolithus nodosus n. gen. n. sp. has a clear prismatic structure which could belong to a dinosauroid prismatic type, but the opening of the pores inside the nodes 

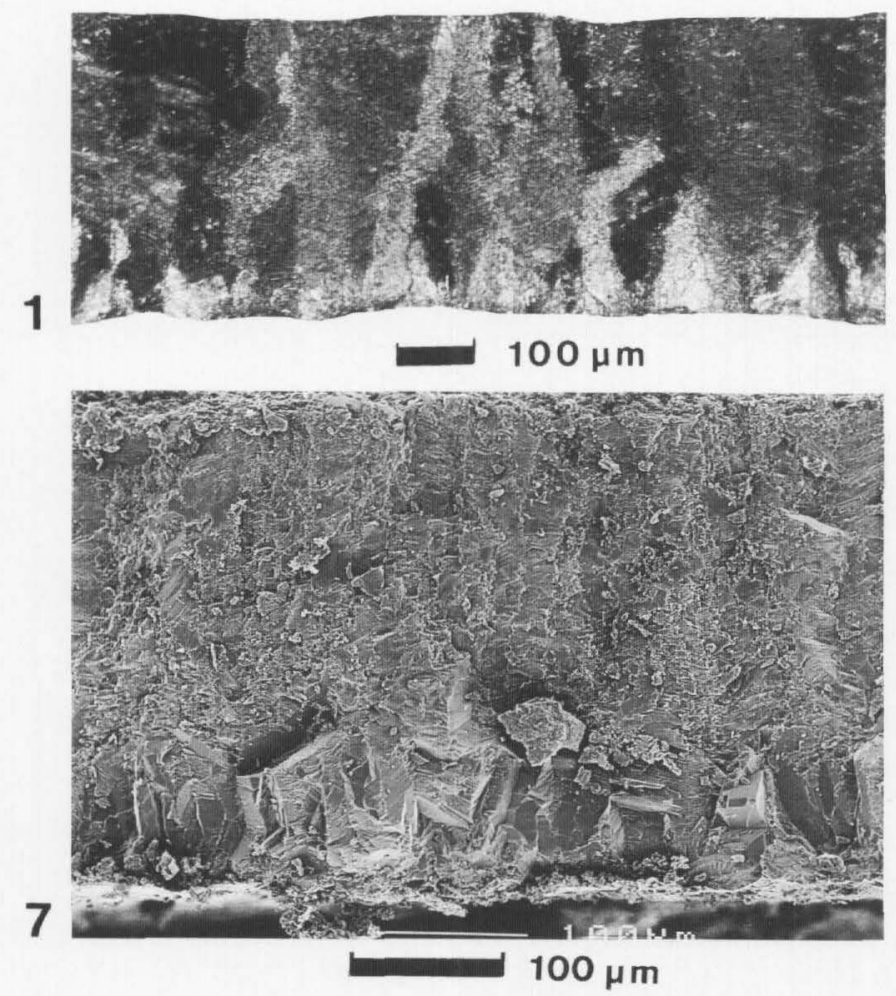

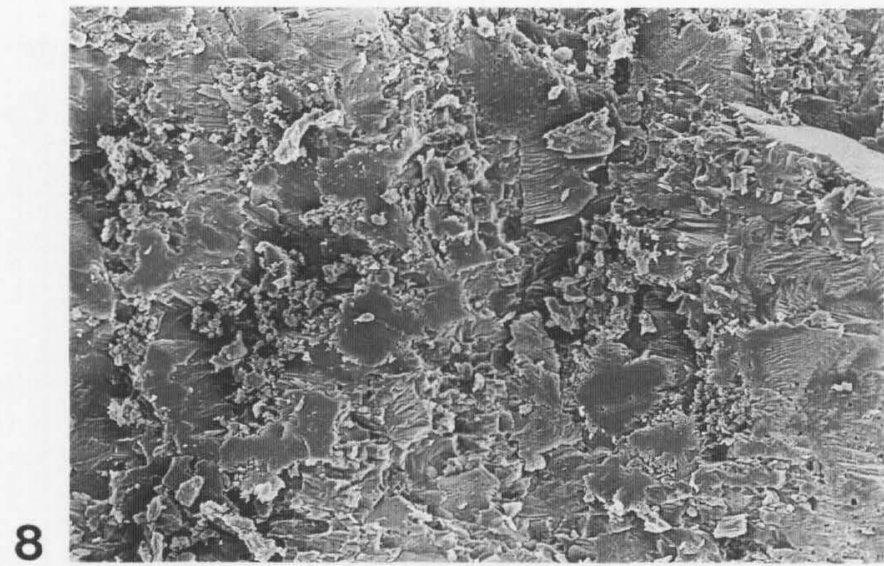

9

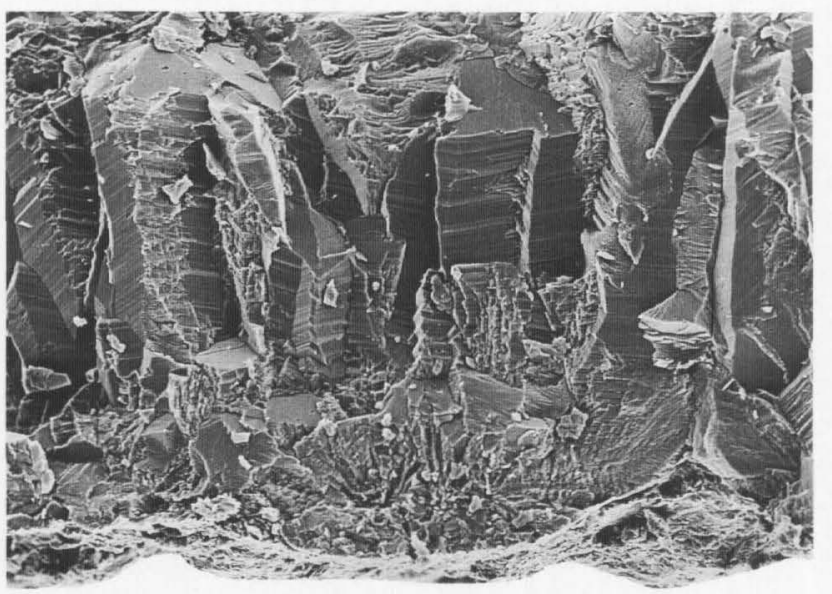

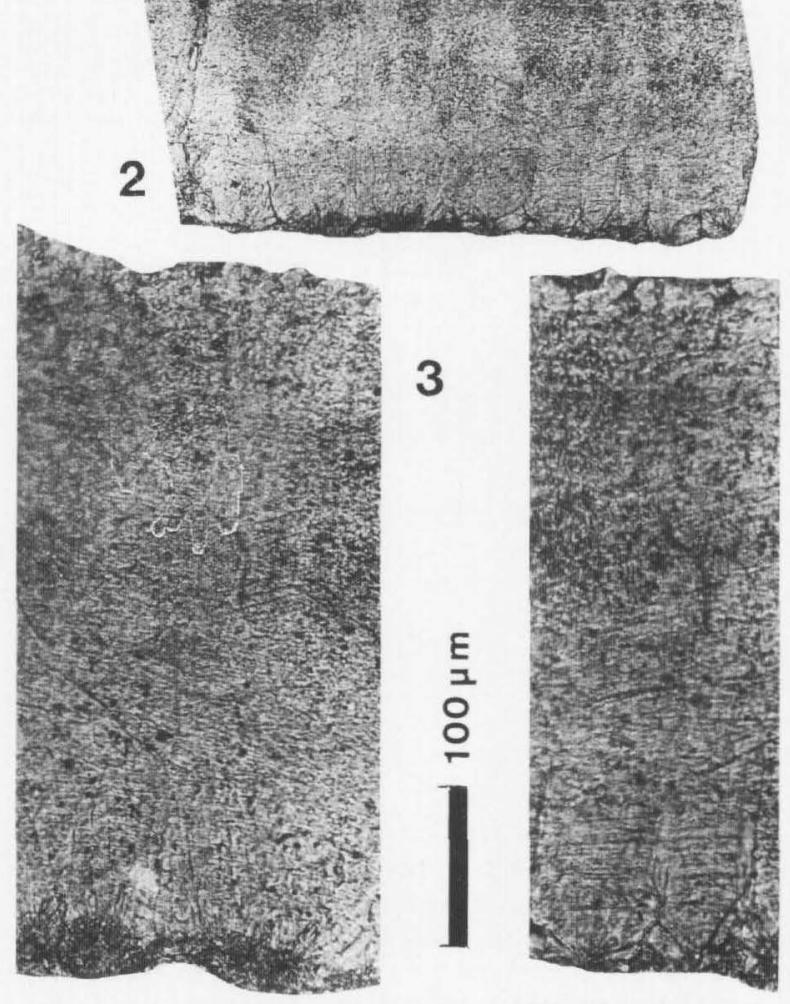
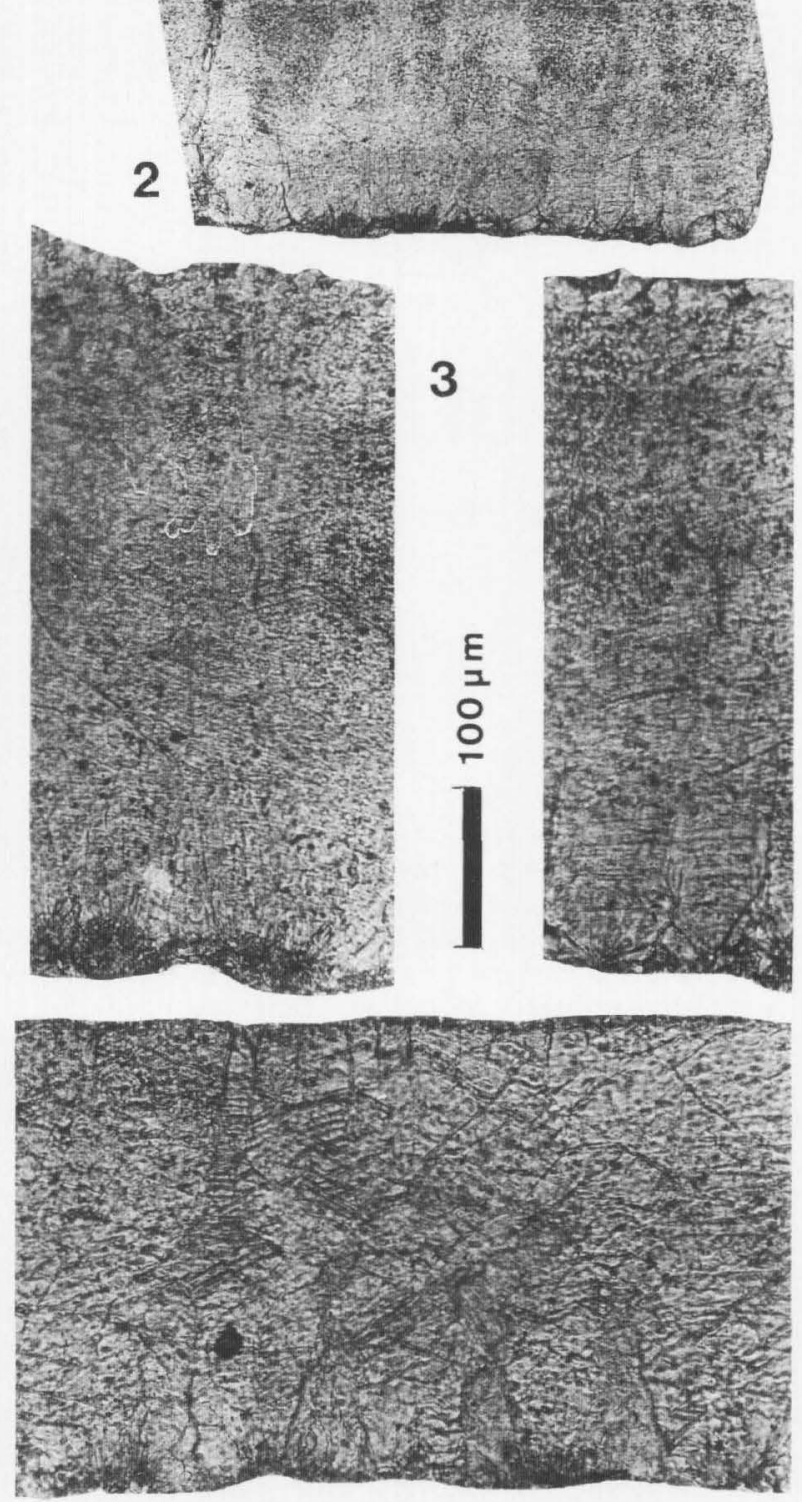

4

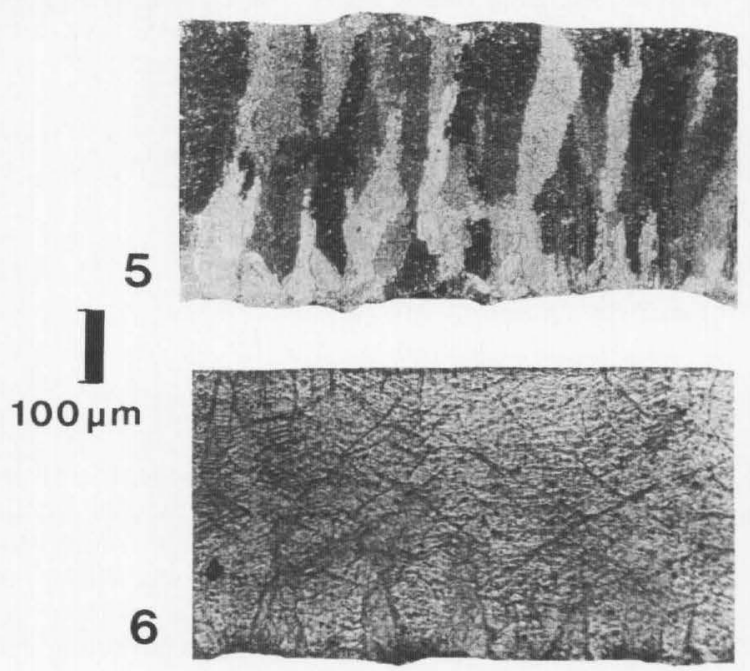


was not yet known in that structural morphotype. The place of the canal in the nodes is similar to that known in recent geckos (Packard and Hirsch, 1989), but the geckoid microstructure seems to be different from that of our specimens. The shell unit of the geckoid type consists of two or three layers (Mikhailov, 1991), although its ultrastructure is still not understood. Packard and Hirsch (1989) note that "the calcareous layer is organized into ill-defined columns, that form a dense crystalline matrix." Pseudogeckoolithus nodosus $\mathrm{n}$. gen. $\mathrm{n}$. sp. has a microstructural and ultrastructural type different from that previously described for geckos (Packard and Hirsch, 1989; Mikhailov, 1991). The question is open whether this oospecies must be separated into a different structural eggshell type.

\section{Basic organizational group ORNITHOID \\ Structural morphotype RATITE. oo-family unnamed \\ AGEROOLITHus new genus}

AGER(OLITHUS FONTLLONGENSIS new genus new species

Figures 9, 10

Diagnosis.-Thin ratite eggshells $(0.25 \mathrm{~mm}$ to $0.36 \mathrm{~mm}$ thick), clearly two-layered, with straight pore canal (15 to 25 $\mu \mathrm{m}$ ) and smooth outer surface; (shape and size of the egg unknown).

Holotype.-FLL6-1, thin section and fragment.

Material.-Nine thin fragments (FLL6-1 to 6).

Type locality and age.-Fontllonga 6 (Lleida, Spain); Early Maastrichtian (Chron 31R);

Description.-The nine small fragments show different kinds of preservation. In all cases, the inner and outer surfaces are somewhat eroded. In addition, recrystallization affects either the outer surface alone, or both surfaces. A thin recrystallized "outer layer" appears in one specimen. In another, besides the outer calcitic recrystallized layer, the whole mammillary layer is recrystallized in small vertical calcitic wedges.

A few, small, smooth fragments show a distinct two-layered structure separated by a sharp limit. Mammillary layer clearly composed of wedges, and single layer not clearly separated in prisms (ratio s. $\mathrm{lm} .1,21$ to $2 / .5$ ). The extinction pattern shows no individual units or columns. A herringbone pattern crosses the boundaries of wedges and columns. Horizontal growth lines are faint in thin sections, and distinct mainly in mammillary layer. The straight pore canal is $15 \mu \mathrm{m}$ to $25 \mu \mathrm{m}$ in diameter

Discussion.-These eggshells can be referred to the Ratite structural morphotype. This type includes several Asiatic families, and at least one of them belongs to a theropod family (Elongaloolithidae, Mikhaillov, 1994). None of these eggs are as thin as the Pyrenean specimens. Some late Cretaceous Peruvian eggshell fragments (Vianey-Liaud et al., 1997) are also Ratite-type, but they are thicker than our Spanish form, and one of them shows ornamentation on the outer surface.

\section{(OTHER TUBFRCLLATE DINOSAUROID \\ EGGSHELLS OF THE TREMP BASIN}

Figures 11, 12

Comparisons.-Tuberculate eggshells were found in several localities in the Tremp Basin: Moro, Biscarri, Abella, Bastus and Sutteranya. The fragments are associated with spherical eggs in
Bastus, Sutteranya and Biscarri, but only scattered fragments have been recovered from Moro and Abella. The identification of the different oospecies is mainly based on the eggshell thickness, the node diameters, shapes of the units and growth lines.

Some eggshell fragments were recovered from the top of the Aren Formation in a rough, grey sandstone at Moro. Most of them are tuberculated (node diameters range from $0.35 \mathrm{~mm}$ to $0.79 \mathrm{~mm}$; average $0.62 \mathrm{~mm}$; thickness about $1.60 \mathrm{~mm}$ ) and belong to Megaloolithus petralta. One thin fragment $(0.48 \mathrm{~mm})$ is referred to Ageroolithus fontllongensis $\mathrm{n}$. gen. $\mathrm{n}$. sp.

The species from Biscarri is easily identified as Megaloolithus siruguei, defined from the French Middle Rognacian (VianeyLiaud et al., 1994).

Although in the specimens from Bastus the preservation of the microstructure is poor (Sanz et al., 1995), due to strong recrystallization, it seems possible to identify the eggs as $\mathrm{Me}$ galoolithus mamillare, defined in the French upper Rognacian. The fragments are characterized by fan-shaped units. The mean diameter of the nodes is about $0.80 \mathrm{~mm}$. The thickness of the eggshells varies from $1.30 \mathrm{~mm}$ to $2.22 \mathrm{~mm}$ (mean $1.77 \mathrm{~mm}$ ). The pore canals are about 90 to $100 \mu \mathrm{m}$. The eggs are spherical, with a diameter of about $20 \mathrm{~cm}$.

The unique specimen from Abella may belong to the same oospecies, $M$. mamillare.

The identification of the fragments from Suterranya is more difficult. Their thickness $(n=48$; range $0.98 \mathrm{~mm}$ to $2.15 \mathrm{~mm}$; average $=1.38$ ) is close to that of the oospecies from Fontllonga 6 , identified as $M$. petralta, but it is also similar to that of $M$. pseudomamillare Vianey-Liaud et al., 1996 from the French late Rognacian ( $=M$. aff. mamillare in Vianey-Liaud et al., 1994, p. 158-162). This species differs from $M$. petralta in its more irregular, and generally slightly wider nodes $(n=59$; range 0.33 $\mathrm{mm}$ to $1.08 \mathrm{~mm}$; average $0.70 \mathrm{~mm}$ ) often coalescing, and by a different growth line pattern. In thin sections, the units are not always well-delimited over the whole thickness, the growth lines continue across adjacent units and often increase in undulation from the base to the top of one unit. The variation in diameter of the node is more important on the Suterranya fragments than in Fontllonga 6 . When the growth lines are preserved, they show increasing undulation upwards. Moreover, the eggs preserved in sandstone lenses are clearly spherical. For these reasons, this oospecies may be distinguished from $M$. petralta and identified as $M$. pseudomamillare.

\section{STRATIGRAPHIC CORRFLATIONS}

The dinosaur eggshells from the Tremp basin allow us to recognize seven oospecies similar to those already described from Southern France (Megaloolithus petralta, cf. $M$. aureliensis, $M$. siruguei, $M$. mamillare, $M$. pseudomamillare, Prismatoolithus tenuis and $P$. aff. matellensis), and four new oospecies, one of them representing a new structural pattern (Pseudogeckoolithus nodusus n. gen. n. sp.) and another a Ratite-type (Ageroolithus fontllongensis $\mathrm{n}$. gen. $\mathrm{n}$. sp.). The oospecies in common allow us to correlate the stratigraphic position of both eggshell successions.

In the well-studied Roquehautes section, in the northern part of the Aix basin (France), $M$. petralta, associated with $M$. aureliensis, is restricted to the lower Rognacian (chron $32 \mathrm{~N}$ and

FIGURE 10-Ageroolithus fontllongensis, from Fontllonga 6. 1-3, radial thin section, FLL-3. 1, polarized; 2, not polarized; 3, same, enlarged, showing the spherulites in the mammillary layer, and the spongy layer; 4-6, radial thin section, FLL6-1, Holotype; 4, not polarized, enlarged; 5 , polarized; 6, not polarized; 7-9, radial section, SEM photographs; 7 , showing the wedges in the mammillary layer, and the spongy layer; 8 , enlarged spongy layer; 9, enlarged zone of wedges in the mammillary layer. 


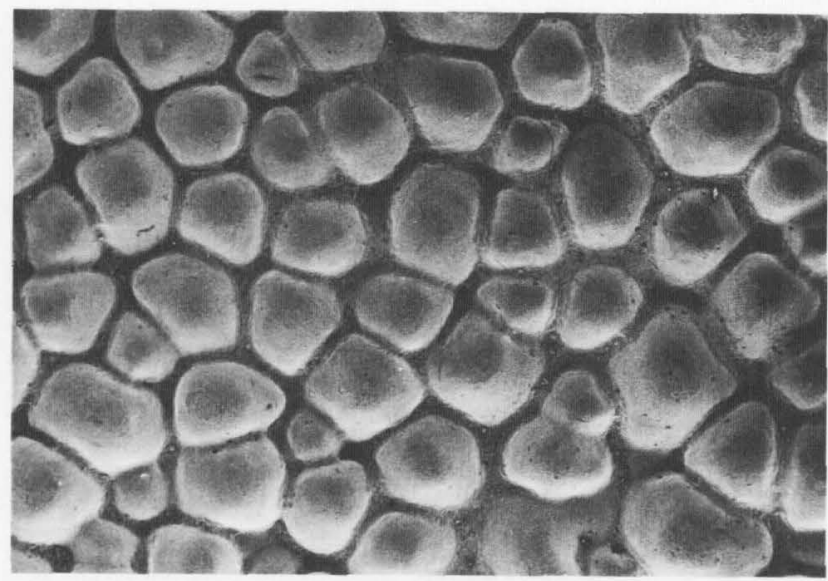

1

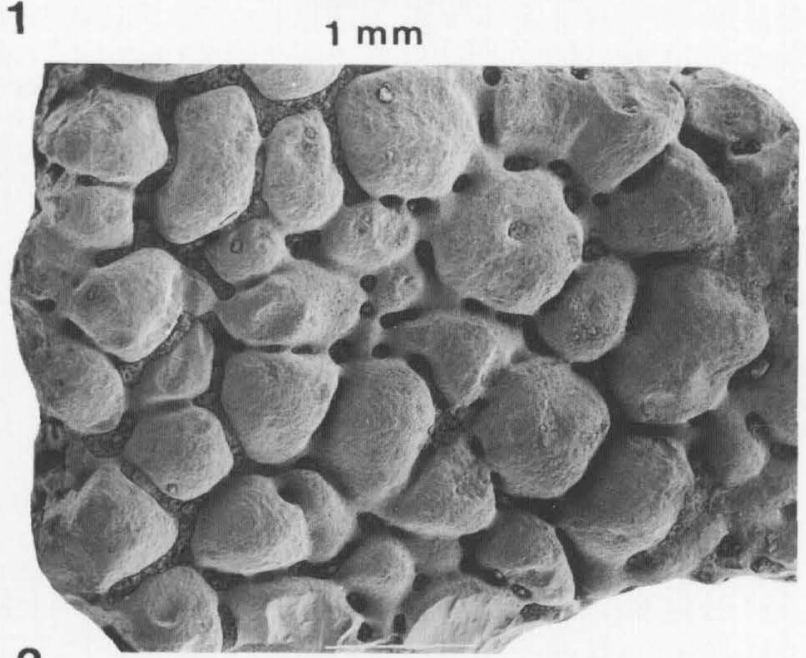

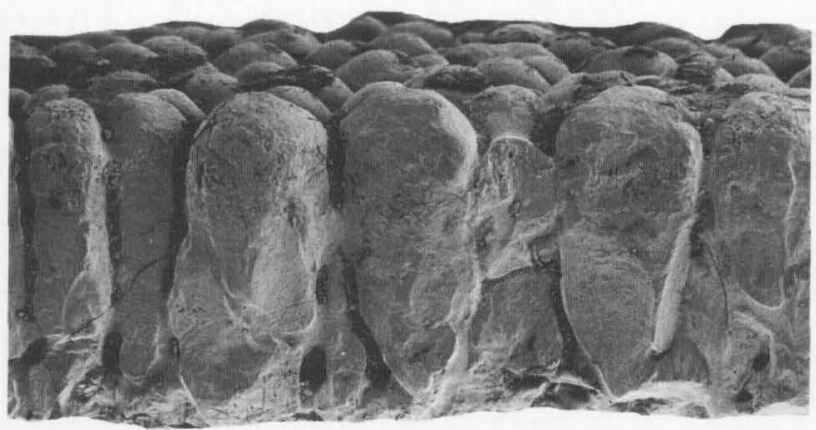

2

$1 \mathrm{~mm}$

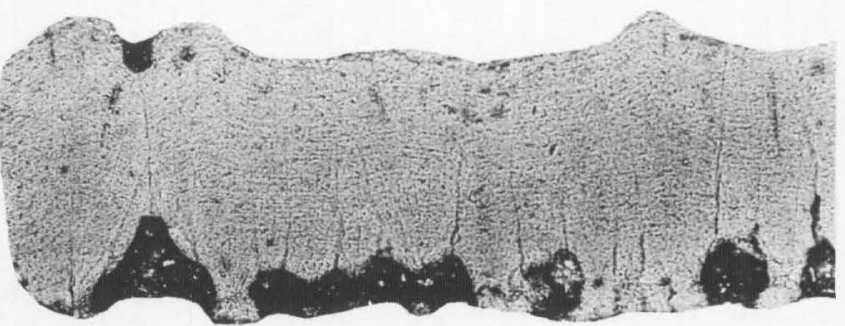

4

$1 \mathrm{~mm}$

3
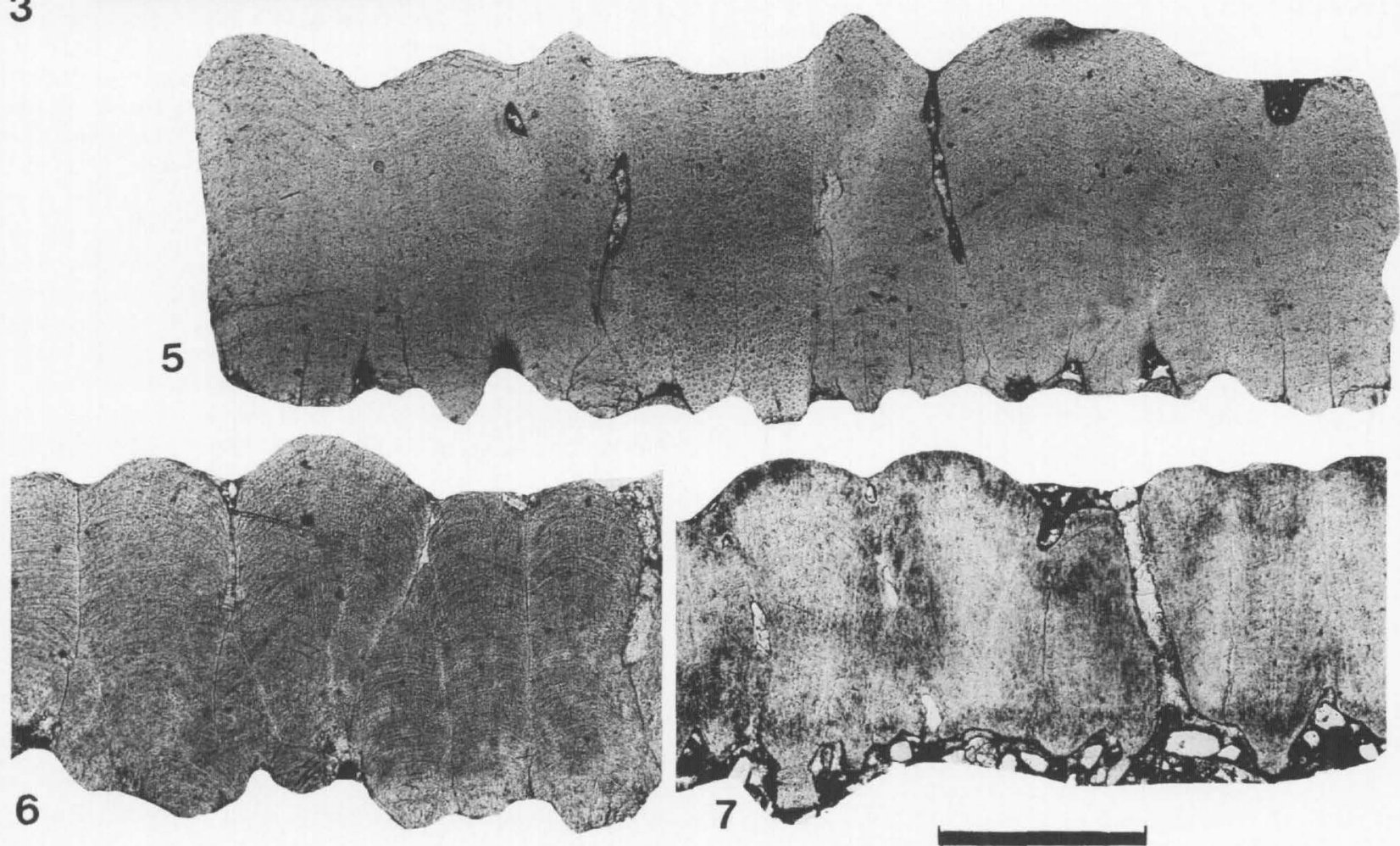


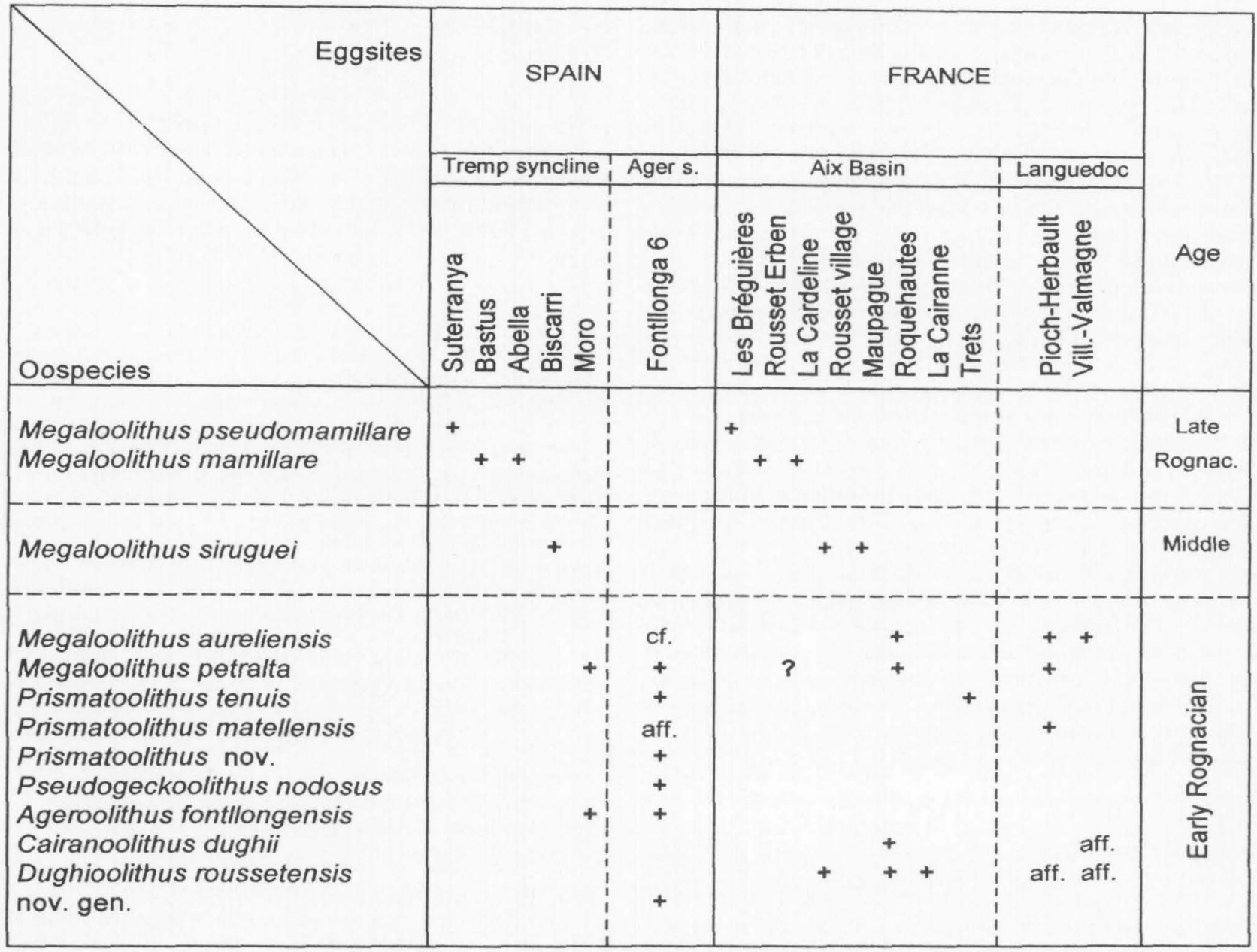

FIGURE 12-Distribution of dinosaur oospecies in the upper Cretaceous localities from the Ager and Tremp synclines (Spain), and Provence and Languedoc (France).

older). Both oospecies are associated with Prismatoolithus tenuis in the Languedoc area (Pioch Herbaut). The eggshell assemblage of Fontllonga 6 and Moro thus coincides with these Lower Rognacian assemblages.

In the south-eastern part of the Arc Syncline (Rousset and La Bégude) $M$. petralta has been questionably identified by some fragments from the upper part of the Rognacian Limestones (middle Rognacian) to the base of the overlying red clays (base of upper Rognacian, chron32R to chron31R). However, this $M$. ?petralta is associated with $M$. mamillare in the upper Rognacian locality (which was not found in Fontllonga 6 or Moro) instead of with $M$. aureliensis which is characteristic of the lower Rognacian.

In all sections of the Aix Basin, from west to east, $M$. siruguei extends clearly from the top of the lower Rognacian to the end of the middle Rognacian (chron $32 \mathrm{~N}$ to base of $31 \mathrm{R}$ ), encompassing the whole Rognac Limestones, and slightly below it. Thus, the Biscarri eggshells correspond to those from the Rognac limestone (middle Rognacian).
In the Rousset section, $M$. mamillare occurs at the beginning of the upper Rognacian red clays (chron $31 \mathrm{~N}$ ?, Westphal and Durand, 1990). Megaloolithus pseudomamillare has been found until now only in the western part of the Arc Syncline (Maupague and Les Bréguiéres sections) in the upper Rognacian red clays, about $30 \mathrm{~m}$ below the Cretaceous-Tertiary boundary (chron 30N, Hansen et al., 1989). Therefore, Abella and Bastús (with $M$. mammilare) and Suterranya (with $M$. pseudomamillare) correlate with the late Rognacian eggshell localities from the Aix basin.

Consequently, if the correlations hold between both sides of the Pyrenees, the eggshell assemblages from Fontllonga 6 and Moro would be the oldest; that of Biscarri would be intermediate in age; and those of Abella, Bastús and Suterranya would correspond to the last dinosaurs of the Pyrenees. The diversity of dinosaur eggshells decreases as we approach the $\mathrm{K} / \mathrm{T}$ boundary, as has also been noticed with the fossil bones of dinosaurs in the Western Interior (Sloan et al., 1986).

The proposed correlations are, however, in contradiction with

FIGURE 11-1, Megallolithus siruguei, from Biscarri, outer surface; 2, the same, radial section, briefly etched. 3, Megaloolithus pseudomamillare, from Suterranya, outer surface; 4 , the same, radial thin section of a thin specimen; 5 , the same, radial thin section of a thick specimen. 6 , Megaloolithus mamillare, from Abella, radial thin section; 7, Megaloolithus mamillare, from Bastus, radial thin section. 
the interpretations based on paleomagnetism and charophytes. Galbrun et al., (1993) correlates the Fontllonga 6 level with the Middle-Upper Rognacian (using charophytes) and the beginning of chron $31 \mathrm{R}$. The lower Rognacian in the Aix basin, with a similar eggshell assemblage, is correlated with the chron $32 \mathrm{~N}$ and older (Westphal and Durand, 1990). Therefore, in Fontllonga 6, Megaloolithus petralta, cf. M. aureliensis, and Prismatoolithus tenuis would appear younger than in the Arc Basin.

Nevertheless, these interpretations may be questioned. Westphal and Durand (1990) admitted that paleomagnetism from western and eastern parts of the Aix basin yielded contradictory results, and remagnetisations seriously flaws the obtained paleomagnetic sequences. The charophyte biostratigraphic succession in the Aix basin does not cover the whole section, but only the Middle Rognacian. Therefore, the correlations according to the eggshell assemblages must also be taken into account.

The dinosaur oospecies shared by the French and Spanish basins allow us to propose a similar succession in both areas. In the Tremp basin, this succession holds for the stratigraphic correlations of the best studied part, the northern flank of the Tremp syncline (Abella, Bastús and Suterranya). The proposed correlations for the rest of the localities agree with the stratigraphic and seismic interpretations of the basinal geometry (Ardévol et al., in press). According to these authors, the younger Maastrichtian depositional sequences thin and wedge out southwards; this corresponds with a younger age of the units northwards, as indicated by the eggshell assemblages. Possibly, future research will reveal the solution to this apparent contradiction between paleomagnetism, charophyte and eggshell successions.

\section{CONCLUSION}

The Fontllonga 6 locality has yielded the most diverse eggshell assemblage known in the European upper Cretaceous (Figure 12). The Dinosauroid Tubospherulitic type is represented by one abundant oospecies (Megaloolithus petralta) and a rare one (cf. $M$. aureliensis); the Dinosauroid Prismatic type is represented by four oospecies, of which two of them at least are new (Prismatoolithidae n. gen. and Pseudogeckoolithus nodosus n. gen. n. sp.); the Ornithoid Ratite is documented by one new oospecies (Ageroolithus fontllongensis $\mathrm{n}$. gen. n. sp.). The relatively high diversity is probably related to the taphonomic conditions of the fossiliferous locality. The eggshells were probably transported from various environments to the lag deposit.

Five other eggshell localities from the Tremp syncline have yielded less diverse associations: $M$. petralta and Ageroolithus $n$. gen. sp. in Moro; $M$. siruguei in Biscarri, $M$. mamillare in Abella and Bastus; and finally $M$. pseudomamillare in Suterranya.

Three successive eggshell assemblages can be recognized in both French and Spanish areas: an older one with Megaloolithus petralta, cf. M. aureliensis and Prismatoolithus tenuis (lower Rognacian in France; Fontllonga 6 and Moro in Spain); an intermediate one with Megaloolithus siruguei (middle Rognacian in France; Biscarri in Spain); and a younger one with M. mamillare, and $M$. pseudomamillare (upper Rognacian in France; Abella, Bastus and Suterranya in Spain).

The stratigraphic correlation with the lower Rognacian based on the eggshell assemblage in Fontllonga 6 does not agree with that provided by the magnetostratigraphic and paleobotanical studies. Either this association is younger in the Ager basin than in the Arc Basin, or contradictions occur between the magnetostratigraphic and charophytes correlations. Resolving these alternatives requires additional studies. In the Tremp basin, the stratigraphic succession of the egg-bearing localities (from older to younger: Moro, Biscarri, Abella, Bastus and Suterranya) agree with the succession established in the Arc Basin (Provence, France).

\section{ACKNOWLEDGMENTS}

We thank M. A. Álvarez-Sierra, L. Ardévol, M. E. Arribas, R. Daams, G. Garcia, J. Guiraud, A. Lacasa, B. Marandat, L. Meslin, A. De la Peña, P. Sevilla, B. Sigé and R. Soler for help with different parts of this work. Financial support has been provided by the DGICYT (Ministerio de Educación y Ciencia), project $n^{\circ}$ PB91-0353; Pub. ISEM n 97.081.

\section{REFERENCES}

Alvarez, W.. L. W. Alvarez. F. Asaro, and H. V. Michel. 1982. Current status of the impact theory for the terminal Cretaceous extinctions. Geological Society of America Special Paper. 190:305-315.

Alvarez-Sierra, M. A. ET AI.. 1994. El límite Cretácico-Terciario en la sección de Fontllonga (Cuenca de Ager, provincia de Lérida). II Congreso Grupo Español del Terciario, Jaca, Comunicaciones:23-26.

ARdévol, L., J. Klimowitz, J. Malagón, and M. Esteban. In press. Depositional sequence response to thrust propagation (Upper Cretaceous Aren Sandstone, South Pyrenean Foreland Basin, Spain. American Association of Petroleum Geology Bulletin.

Arribas, M. E., L. Ardévol, and N. López-Martínez. 1996. Peritidal lacustrine carbonates, Upper Cretaceous of Southern Pyrenees, Spain. XVII Congress International Association of Sedimentologist. Abstract Book. Tunis.

Cuevas, J. L., T. Dreyer, and L. Mercadé. 1989. The first stage of the forcland basin: the Tremp Group, p. 23-29. In C. Puigdefábregas, W. Nijman, and J. A. Muñoz, (eds.), Guidebook 4th Int. Conference on Fluvial Sedimentology, Publicacio Servei Geològic de Catalunya.

Díaz Molina, M. 1987. Sedimentación sintectónica asociada a una subida relativa del nivel del mar durante el Cretácico superior, p. 6993. In J. L. Sanz (cd.), Geología y Paleontología (Arcosaurios) de los yacimientos cretácicos de Galve (Teruel) y Tremp (Lérida). Estudios Geológicos, volumen extraordinario Tremp-Galve.

Durand, J. P. 1989. Le synclinal de l'Arc et la limite Crétacé-Paléocéne, p. 2-10. In La limite Crétacé-Tertiaire dans le synclinal de l'Arc. Cahiers de la Réserve géologique de Haute Provence, Digne.

Erben, H. K., J. Hoefs, AND K. H. WedePohl. 1979. Paleobiological and isotopic studies of eggshells from a declining dinosaur species. Paleobiology, 5:380-414.

FASSET, J. E., AND J. K. RigbY, (eds.). 1987. The Cretaceous-Tertiary boundary in the San Juan and Raton basins, New Mexico and Colorado. Geological Society of America Special Paper, 209, 200 p.

FAstovsky, D. E. 1987. Paleoenvironments of Vertebrate-bearing strata during the Cretaceous-Paleogene transition, Eastern Montana and Western North Dakota. Palaios. 2:282-295.

Galbrun, B., M. Feist, F. Colombo, R. Rocchia, and Y. Tambareau. 1993. Magnetostratigraphy and biostratigraphy of Cretaceous-Tertiary continental deposits, Ager basin, province of Lerida, Spain. Palaeogeography, Palaeoclimatology, Palaeoecology, 102:41-52.

Gradstein, F. M., ET AL. 1995. A Triassic, Jurassic and Cretaceous time scale, p. 95-126. In W. A. Berggren, D. V. Kent, M. P. Aubry. and J. Hardenbol, (eds.). Geochronology, time scales and global stratigraphic correlation. Socicty of Economic Palcontology and Mineralogy. Special Publication, 54.

Hansen, H. J., R. Gwozdz, and K. L. Rasmussen. 1989. The continental Cretaceous/Tertiary boundary in the Aix-en-Provence Basin. South France. A preliminary paleomagnetic study, p. 43-50. In La limite Crétacé-Tertiaire dans le synclinal de l'Arc. Cahiers de la Réserve géologique de Haute Provence, Digne.

HIRSCH, K. 1994. Upper Jurassic eggshells from the Western Interior of North America, p. 138-150. In K. Carpenter, K. Hirsch, and J. R. Horner (eds.). Dinosaur Eggs and Babies, Cambridge Lniversity Press.

Keller, G., aND E. Barrera. 1990. The Cretaceous/Tertiary boundary impact hypothesis and the paleontological record, p. 563-575. In V. L. Sharpton. and P. D. Ward (eds.), Global catastrophes in Earth history: an interdisciplinary conference on impacts, volcanism and mass mortality. Geological Society of America Special Paper, 247.

Krauss, S. 1990. Stratigraphy and facies of the "Garumnian"-Late Cretaceous to Early Palcogene-in the Tremp region, Central 
Southern Pyrenees. Tübinger Geowissenchaftliche Arbeiten, 11:1152.

Lerbekmo, J. F.. A. R. Sweet, and R. M. St Louis. 1987. The relationship between the iridium anomaly and palynological floral events at three Cretaccous-Tertiary boundary localities in Western Canada. Geological Socicty of America Bulletin, 99:325-330.

Liebau, A. 1973. El Maastrichtiense lagunar ("Garumniense") de Isona. XIII Congreso Europeo Micropaleontologia, ENADIMSA, Madrid: $87-112$.

López-Martínez, N., L. Ardévol, M. E. Arribas-Mocoron, J. Civis, AND A. GonZalfz-Delgado. 1996. Transición Cretácico-Terciario en depósitos continentales de la cuenca de Tremp-Graus: datos preliminares de isótopos estables de C.y O. IV Congreso Geológico de España, Alcalá de Henares. Geogaceta, 20:54-57.

losantos, M., E. Aragones, X. Berastegli, J. Palau, and C. PuigDEFABREGAS. 1989. Mapa geològic de Catalunya 1:250.000, Servei Geologic Generalitat de Catalunya.

Mey, P.. P. NagtegaAi., K. Roberti, and J. Hartevelt. 1968. Lithostratigraphic subdivision of post-Hercynian deposits in the south central Pyrenees, Spain. Leidse Geolische Mededelungen, 41:221-228.

Mikhaílov, K. E. 1991. Classification of fossil eggshells of amniotic vertebrates. Acta Palcontologica Polonica, 36:193-238.

1994. Theropod and Protoceratopsian Dinosaur Eggs from the Cretaceous of Mongolia and Kazakhstan. Paleontological Journal, 28(2): 101-120

Moratalla, J. J. 1993. Restos indirectos de dinosaurios del registro español: paleoicnología de la cuenca de Cameros (Jurásico superiorCretácico inferior) y Paleoología del Cretácico superior. Unpubl. Tesis Doctoral, Universidad Autónoma Madrid, 727 p.

NagtegaAl, P. J. C., A. Van Vliet, and J. Brouwer, 1983. Syntectonic coastal offlap and concurrent turbidite deposition: the Upper Cretaccous Aren Sandstone in the South-Central Pyrenees, Spain. Sedimentary Geology, 34:185-218.

ORTH, C. J., ET AL. 1981. An iridium abundance anomaly at the palynological Cretaceous-Tertiary boundary in Northern New Mexico. Science, 214:1341-1343.

PACKARD, M. J., AND K. HiRsCh. 1989. Structure of shells from eggs of the geckos Gecko gecko and Phelsuma madagascarensis. Canadian Journal of Zoology, 67:746-758.

Pons, J. M. 1977. Estudio estratigráfico y paleontológico de los yacimientos de rudístidos del Cretácico Superior del Prepirineo de la provincia de Lérida. Tesis Doctoral, Publicaciones Geologia Universidad Autonoma Barcelona, 3:1-105.

Rosell. J. 1967. Estudio geológico del sector del Prepirineo compren- dido entre los ríos Segre y Noguera Ribagorzana (Provincia de Lérida). Pirineos, 75:5-225.

—, AND C. Llompart. 1988. Guia geològica del Montsec i de la vall d'Ager. Publicacions Centre Excursioniste Catalunya, $168 \mathrm{p}$.

SAHNI, A., ET AL. 1994. Upper Cretaceous dinosaur eggs and nesting sites from the Deccan volcano-sedimentary province of peninsular India, p. 204-226. In K. Carpenter, K. Hirsch, and J. R. Horner (eds.), Dinosaur Eggs and Babies. Cambridge University Press.

SANZ, J. L., ET AL. 1995. Dinosaur nest at the sea shore. Nature, 376 $731-732$.

SloAn, R. E., J. K. Rigby, L. M. Van Valen, and D. Gabriel. 1986 Gradual dinosaur extinction and simultaneous ungulate radiation in the Hell Creek Formation. Science, 232:629-633.

Soler-Gión, R., AND N. López-Martínez. 1995. Selaceos y Batoideos (Condrictios) del Cretacico superior de la cuenca de Tremp (Pirineo Central, Lleida), p. 173-176. In G. López, A. Obrador, and E. Vicens (eds.), XI Jornadas de Paleontologia. Tremp.

Souquet, P. 1967. Le Cretacé supérieur sud-pyrénéen en Catalogne, Aragón et Navarre. Thèse Doctorat Université Toulouse, $529 \mathrm{p}$.

VerGÉs, J., AND J. A. MLÑOZ. 1990. Thrust sequences in the southern central Pyrenees. Bulletin Société Géologique de France, 8:265-271.

Vianey-Liaud, M., AND J.-Y. Crochet. 1993. Dinosaur eggshells from the late Cretaceous of Languedoc (Southern France). Revue de Paléobiologie, Genève, 7:237-249.

- P. Mallan, O. Buscail, and C. Mongelard. 1994. Review of French dinosaur eggshells: morphology, structure, mineral, and organic composition, p. 151-183. In K. Carpenter, K. Hirsch, and J. R. Horner (eds.), Dinosaur Eggs and Babies. Cambridge University Press.

- K. Hirsch, A. Sahni, and B. Sigé. 1997. Late Cretaceous Peruvian eggshells and their relationships with Laurasian and Eastern Asian material. Geobios, 30,1:75-90.

Westphal, M., AND J. P. DuRand. 1990. Magnétostratigraphie des séries continentales fluvio-lacustres du Crétacé supérieur dans le synclinal de l'Arc (région d'Aix-en-Provence, France). Bulletin de la Société géologique de France, Paris. 8 (6), 4:609-620.

ZHAO, Z. 1975. The microstructure of the dinosaur eggshells of Nanshiung, Kwantung. Vertebrata PalAsiatica. 13:105-117.

- 1979. The advancement of researches on the dinosaurian eggs in China, p. 329-340. In South China Mesozoic and Cenozoic "Red Formation". Beijing: Science Publishing Co.

- AND R. LI. 1993. First record of late Cretaceous Hypsilophodontid eggs from Bayan Manduhu, Inner Mongolia: Vertebrata PalAsiatica, 31:77-84. 